\title{
Article \\ Phytochemical and Nutritional Profile Composition in Fruits of Different Sweet Chestnut (Castanea sativa Mill.) Cultivars Grown in Romania
}

\author{
Corina Teodora Ciucure ${ }^{1,2}$, Elisabeta-Irina Geana ${ }^{1, *} \mathbb{C}$, Claudia Sandru ${ }^{1}$, Ovidiu Tita ${ }^{2} \mathbb{C}$ and Mihai Botu ${ }^{3, *}$ \\ 1 National Research and Development Institute for Cryogenics and Isotopic Technologies-ICSI, \\ 240050 Rmmnicu Valcea, Romania; corina.ciucure@icsi.ro (C.T.C.); claudia.sandru@icsi.ro (C.S.) \\ 2 Faculty of Agricultural Science, Food Industry and Environmental Protection, Lucian Blaga \\ University of Sibiu, 550012 Sibiu, Romania; ovidiu.tita@ulbsibiu.ro \\ 3 Department of Horticulture and Food Science, Faculty of Horticulture, University of Craiova, A.I. Cuza 13 Str., \\ 200585 Craiova, Romania \\ * Correspondence: irina.geana@icsi.ro (E.-I.G.); mihai.botu@edu.ucv.ro (M.B.)
}

check for updates

Citation: Ciucure, C.T.; Geana, E.-I.; Sandru, C.; Tita, O.; Botu, M. Phytochemical and Nutritional Profile Composition in Fruits of Different Sweet Chestnut (Castanea sativa Mill.) Cultivars Grown in Romania. Separations 2022, 9, 66. https://doi.org/10.3390/ separations 9030066

Academic Editor: Javier Saurina

Received: 8 February 2022

Accepted: 25 February 2022

Published: 2 March 2022

Publisher's Note: MDPI stays neutral with regard to jurisdictional claims in published maps and institutional affiliations.

Copyright: () 2022 by the authors. Licensee MDPI, Basel, Switzerland. This article is an open access article distributed under the terms and conditions of the Creative Commons Attribution (CC BY) license (https:// creativecommons.org/licenses/by/ $4.0 /)$.

\begin{abstract}
Chestnut (Castanea sativa Mill.), a valuable fruit crop, is cultivated in small areas in Romania, mostly in the west, where the moderate continental climate has a slight Mediterranean influence. This work aims to investigate the bioactive characteristics (total polyphenols, total flavonoids and antioxidant activity), individual polyphenolic composition, phytochemical and nutritional HRMS screening profiles, sugar and mineral composition of six sweet chestnut cultivars, namely 'Marsol', 'Maraval', 'Bournette', 'Précoce Migoule' and 'Marissard' grown at Fruit Growing Research-Extension Station (SCDP) Vâlcea, in Northern Oltenia, Romania. Fruit samples were collected in two consecutive years, in order to study the impact of genetic variability between cultivars and the influence of the different climatic conditions corresponding to different cultivation years. Principal Component Analysis (PCA) and Hierarchical Cluster Analysis (HCA) allow the discrimination between the sweet chestnut fruits harvested in different years and different sweet chestnut cultivars. Analytical investigations revealed that sweet chestnut cultivars grown in Romania show similar bioactive, phytochemical and nutritional composition to cultivars grown in the large European chestnut-producing countries, indicating the high adaptation potential of the chestnut in the temperate continental zone with small Mediterranean influences characteristic of the southwestern area of Romania.
\end{abstract}

Keywords: sweet chestnut; bioactive characteristics; phenolic compounds; HRMS fingerprints; sugar profile; mineral composition; statistical analysis

\section{Introduction}

The sweet chestnut is the fruit of the Castanea sativa Mill., which belongs to the genus Castanea, of the Fagaceae family, and is cultivated especially in Mediterranean Europe [1]. Sweet chestnut is an important resource in Europe due to its economic value associated with fruit, wood and tannin production and indirectly with honey production, but also due to its cultural value [2]. Castanea sativa Mill. is also commonly known as European chestnut and has a large distribution in Spain, France, Greece, Italy, Portugal, and Turkey [3].

Nutritionally, chestnuts have interesting characteristics, containing significant amounts of carbohydrate dietary fiber, but small amounts of crude protein (2-4\%) and low levels of crude fat (predominated by unsaturated fatty acids) $(2-5 \%)$ compared to typical walnuts (walnuts, almonds, hazelnuts) [4,5], thus being a good source of energy with multiple health-beneficial effects. Chestnuts are also low in fat, thus helping to decrease cholesterol levels and they contain a high amount of vitamin $\mathrm{C}$, macro- $(\mathrm{K}, \mathrm{P}, \mathrm{Mg}, \mathrm{Ca}, \mathrm{Na})$ and micronutrients $(\mathrm{Mn}, \mathrm{Fe}, \mathrm{Zn}$ and $\mathrm{Cu}$ ) [6]. The fruits also have a significant antioxidant activity associated with polyphenolic and organic contents [7]. 
Thus, chestnut fruits have become very important in the human diet due to their nutritional composition and health benefits, for example, their use in gluten-free diets in celiac disease [8], reducing abdominal adiposity [9] and reducing coronary heart disease and cancer rates [3]. The growing demand for traditional foods has converted chestnuts into a value-added resource with considerable potential as functional foods or food ingredients. The nuts are consumed in roasted or boiled form or for the development of different added value products in the cake and candy industry [10]. Considering the fact that cooked chestnuts are a good source of phenolics (gallic and ellagic acids) and organic acids (citric acid) and have low fat contents [7], properties that are associated with positive health benefits, the development of new products based on chestnuts should be encouraged [11]. Therefore, over the last few decades, the chestnut industry has significantly grown in Europe, especially in the production of marron glacé, purées and chestnut flour, which find increasing application as an ingredient in gluten-free diets [12], such as the production of pasta by incorporating chestnut flour and bee pollen [13]. In addition, chestnut extracts can be used in the food industry as functional ingredients and natural preservatives aiming to replace the synthetic ones capable of improving the shelf-life and nutritional value of products [14,15]. Furthermore, chestnut shells as the main byproduct generated from chestnut processing are currently used as fuels [16], for the production of lignin biopolymer and bioethanol following a biorefinery approach [17], but also can be a source of hydrolyzable tannins as natural pigments for food and pharmaceutical industries [18], as a bioactive ingredient for nutraceutical and cosmetic industries [14]. Different marketed food supplements (sold as tablets or capsules) and herbal medicinal products (powders, extracts, essential oil) based on chestnuts have been obtained over time in order to protect the health of the population.

Therefore, due to the increased economic interest in the use of sweet chestnuts in the food industry, there was a need to develop selected cultivars with enormous potential on human health associated with the consumption of chestnuts and processed products based on chestnuts [19]. Additionally, in order to increase chestnut production and resistance to chestnut-specific diseases, some hybrids have appeared over time [11].

The nutritional composition and bioactivity of fresh sweet chestnuts show differences between cultivars [2,20], producing regions, harvesting year [21], soil and climatic conditions (temperature, sun exposure and precipitation) [22], but also cultivation techniques, for example, nutrients, minerals, irrigation and diseases and pests [23,24].

The increased market demand and consumer awareness imposes the development of reliable methods able to distinguish between different cultivars, highlighting high quality products in terms of sensorial and qualitative properties and high bioactive composition. In the last few decades, different methodologies have been used to characterize and distinguish between different sweet chestnut cultivars, including morphological characteristics [25] and chemical composition addressing the proximate analysis including dry mass, ash quantity, total fat, total protein $[7,26]$, total carbohydrates, total sugar, invert sugar, starch, sucrose [3], but also mineral contents ( $\mathrm{Ca}, \mathrm{Mg}$, Fe, Mn, $\mathrm{Cu}, \mathrm{Zn}, \mathrm{P}, \mathrm{Na}$ and $\mathrm{K}$ ) [3,4,27], total polyphenols (mg GAE/g) and antioxidant activity ( $\mu \mathrm{mol}$ Trolox equivalent/g) dry weight basis [4,5] and organic acids (oxalic, cis-aconitic, citric, ascorbic, malic, quinic and fumaric acids) [7,28], free amino acids [26], sugars profile [29,30].

For decades, conventional extraction methods including maceration or Soxhlet extraction using different polar solvents (methanol, ethanol, chloroform and petroleum ether) were the most used to extract bioactive compounds from a natural matrix, and which, due to environmental, economic and safety concerns, presents a huge limitation for an industrial application. Given these disadvantages, more sustainable extraction methods, including ultrasonic extraction, microwave extraction, supercritical fluid extraction and enzymatic extraction were promoted for the extraction of polar bioactive compounds from natural sources [18,31].

Chestnut growing areas in Romania cover a total area of 3160 ha distributed on a discontinuous area, consisting of long bands situated on the foothills of the Carpathians, 
mostly in the west part of Romania, where the moderate-continental climate has a slight Mediterranean influence. Chestnut natural distribution cover two principal centers, namely Maramures (the hilly foothills of Baia Mare) and Oltenia (subcarpathian hills of Oltenia on the territory of Gorj, Mehedinţi and Vâlcea counties) and other several small areas on Southeast of the Oriental Carpathians and Northwest and Southwest of Transylvanian plateau [32]. The semi-spontaneous flora of Northern Oltenia contains many biotypes of sweet chestnut (Castanea sativa Mill). Since 1998, several French cultivars, which are hybrids between Japanese chestnut (Castanea crenata Siebold \& Zucc.) and European chestnut (Castanea sativa Mill.) were introduced at the Fruit Growing Research-Extension Station (SCDP) Vâlcea for testing and they have proved to yield well in the given conditions. Physical characteristics (diameters, height, shape index and size index, mass, volume and specific weight), nutritional composition (water (\%), titrable acidity (g malic acid/100 g), lipids (\%), proteins (\%) and bioactive characteristics (total polyphenols, total flavonoids, antioxidant activity and some individual polyphenolic compounds) of these cultivars were previously addressed [33] and supplementary characteristics are required in order to make a detailed characterization and comparison of these six chestnut cultivars, in order to provide valuable information for selection of the chestnut cultivar with high quality bioactive characteristics that can be cultivated for the development of different value-added food products with multiple benefits on human health.

Therefore, this work aims to strengthen our knowledge about the chemical and nutritional composition of the six sweet chestnut cultivars of French origin, namely 'Marsol', 'Maraval', 'Bournette', 'Précoce Migoule' and 'Marissard' in order to find distinctive features useful for authenticating a certain chestnut cultivar, providing an important economic advantage. For that, the bioactive characteristics (total polyphenols, total flavonoids and antioxidant activity) examined by UV-Vis spectrophotometric methods, UHPLC-MS/MS phenolic compound profile (phenolic acids, flavonoids), together with a non-target UHPLC-MS/MS screening profile, the sugar profile (sucrose, fructose, glucose, maltose) by HPLC-ELSD and elemental composition (Ca, $\mathrm{Mg}, \mathrm{Na}, \mathrm{K}, \mathrm{Fe}, \mathrm{Pb}, \mathrm{Ni}, \mathrm{Cu}, \mathrm{Cr}$ ) by F-AAS were determined in the studied chestnut cultivars in order to complete the information about the nutritional and bioactive composition of all these cultivars. In addition, we studied the influence of the harvest year on the bioactive characteristics and the content of the specific bioactive compounds. Principal Component Analysis (PCA) and Hierarchical Cluster Analysis (HCA) were used in order to discriminate between the different sweet cultivars grown in Romania.

\section{Materials and Methods}

\subsection{Plant Material and Sampling Site}

Fruit samples were collected from a field trial planted in 1998 at Fruit Growing ResearchExtension Station (SCDP) Vâlcea, located in Bujoreni $\left(45^{\circ} 08^{\prime} 26.55^{\prime \prime} \mathrm{N} ; 24^{\circ} 22^{\prime} 01.02^{\prime \prime} \mathrm{E}\right)$, near Râmnicu Vâlcea, in the Southwest of Romania. SCDP Vâlcea belongs since 2010 to the University of Craiova. The trial contains French sweet chestnut cultivars as: 'Précoce Migoule CA 48', 'Bournette CA 112', 'Marsol CA 07', 'Marissard CA 122', 'Marigoule CA 15 ' and 'Maraval CA 74', all of them provided by INRA-UREFV Bordeaux, France. Trees are grafted on Castanea sativa seedling rootstock and were planted in the trial orchard in 1998 and were grown under the same pedoclimatic conditions and agronomic management practices at SCDP Valcea, Northern Oltenia, Romania. The orchard soil was alluvial, clayey-loam type, slightly acid ( $\mathrm{pH}=5.2)$, the mineral content level was good, and organic matter level was poor. The climate is fairly mild, and annual rainfall is about $700-800 \mathrm{~mm}$. Chestnut fruits were harvested at maturity, at the end of September through the middle of October, during two consecutive years (2016 and 2017). They were collected randomly from different trees, for each cultivar $1 \mathrm{~kg}$ of samples were collected and within a week from harvest, the nuts were hand peeled and then dehydrated at $40{ }^{\circ} \mathrm{C}$ using a Biovita drier (Globus Transport, Cluj Napoca, Romania), ground to fine powder by using a Retsch 
200 mill (Verder Scientific, Haan, Germany) and then lyophilized (Labconco freeze dryer) (Labconco Corporation, Kansas, MO, USA) for further analysis.

\subsection{Standards and Reagents}

All solvents were of high-performance liquid chromatography (HPLC) grade purchased from Merck (Darmstadt, Germany) (methanol, acetonitrile), Folin-Ciocalteu phenol reagent $(2 \mathrm{~N})$, radical scavenging assay reagents DPPH and 6-hydroxy-2,5,7,8-tetramethyl2-carboxylicacid (Trolox) were purchased from Sigma-Aldrich (St Louis, MO, USA) and ultra-pure water was produced by a Milli-Q Millipore system (Bedford, MA, USA). Other reagents (formic acid, nitric acid, hydrogen peroxide) were analytical grade and purchased from Merck (Darmstadt, Germany). Phenolic standards (gallic, syringic, p-coumaric, caffeic, chlorogenic, ferulic, p-hydroxybenzoic, 3,4-dihydroxybenzoic and trans-cinnamic acids; $(+)$-catechin and (-)-epicatechin, rutin, quercetin, naringin, hesperitin, myricetin, apigenin, galangin, kaempferol, isorhamnetin, chrysin, pinocembrin, pinostrobin and resveratrol) and sugar standards (glucose, fructose, sucrose and maltose) were purchased from SigmaAldrich (Steinheim, Germany). High purity multielement calibration standard solution ICP Multi-Element Standard Solution IV CertiPUR $(1000 \mathrm{mg} / \mathrm{L}$ of each element in HNO3 $65 \%)$, and ICP Multi-Element Standard Solution XXI CertiPUR $(10 \mathrm{mg} / \mathrm{L}$ of each element in HNO3 65\%) were purchased from Merck KGaA Frankfurter, Darmstadt, Germany.

\subsection{Extraction Protocols}

Polyphenolic compounds were extracted from freeze-dried subsamples $(0.25 \mathrm{~g})$ using a $25 \mathrm{~mL}$ mixture of methanol: water $(70: 30, v / v)$, under the action of ultrasound, at a temperature of $60^{\circ} \mathrm{C}$, for $30 \mathrm{~min}$. The resulted suspension was centrifuged at 10,000 rpm for $15 \mathrm{~min}$ and the supernatant was concentrated at $40^{\circ} \mathrm{C}$ under reduced pressure using a TurboVap MP6 (Buchi, Switzerland) and then diluted with methanol to a final volume of $3 \mathrm{~mL}$. The resulting extracts were filtered through $0.45 \mu \mathrm{m}$ PTFE (polytetrafluoroethylene) membrane syringe filters (Merck Millipore, Darmstadt, Germany) before the UV-Vis spectrophotometric and UHPLC-MS/MS determinations.

Sugars were extracted from a $2.5 \mathrm{~g}$ sample using $10 \mathrm{~mL}$ ultrapure water, under ultrasounds, at $60^{\circ} \mathrm{C}$, for $30 \mathrm{~min}$. The resulting suspension was centrifuged at $10,000 \mathrm{rpm}$ for $10 \mathrm{~min}$, followed by the quantitative recovery of the analytes by two washing steps. The combined extracts were diluted with ultrapure water to a final volume of $20 \mathrm{~mL}$, followed by filtration through $0.45 \mu \mathrm{m}$ PTFE membrane syringe filters before HPLC-ELSD determination.

In order to estimate the elemental content, chestnut samples were extracted by microwave acid digestion using a TOP microwave sample preparation system (Analytik Jena, Jena, Germany) equipped with closed Teflon vessels. In brief, $0.4 \mathrm{~g}$ of sample was placed in the Teflon digestion vessel previously cleaned with $10 \%$ nitric acid, followed by the addition of $6 \mathrm{~mL}$ of concentrated nitric acid 65\% (spectroscopic grade, Merck, Darmstadt, Germany) and $1 \mathrm{~mL}$ of hydrogen peroxide $30 \%$ were added. The vessels were closed and placed in the rotor, followed by the application of the digestion program composed by three step temperature programs, namely: (i) pressure 40 bar, ramp $5 \mathrm{~min}$, temperature $170{ }^{\circ} \mathrm{C}$, time $10 \mathrm{~min}$; (ii) pressure $40 \mathrm{bar}$, ramp $1 \mathrm{~min}$, temperature $200{ }^{\circ} \mathrm{C}$, time $15 \mathrm{~min}$; and (iii) cooling. After the digestion process, digested samples were quantitatively transferred with ultra-pure water into a $50 \mathrm{~mL}$ volumetric flask, filtered and then subjected to F-AAS determination.

\subsection{Analytical Determinations}

2.4.1. Determination of Total Phenolic (TP) and Total Flavonoid (TF) Contents and Antioxidant Activity (AA) by UV-Vis Spectrophotometric Determinations

Colorimetric spectrophotometric determinations of the chestnut extracts (total polyphenols - TP, total flavonoids- TF and antioxidant capacity- AC) were performed using a Specord 250 Plus UV-Vis spectrophotometer (Analytic Jena, Germany) equipped with $1 \mathrm{~cm}$ path length quartz cells. The total polyphenol content (TP) was evaluated following 
the Folin-Ciocalteu colorimetric method as presented by Ciucure et al. [34], using gallic acid as a reference substance, while total flavonoids content (TF) was determined by the aluminum chloride method as previously presented [35], using rutin as reference substance. Antioxidant capacity in the chestnut fruits was assessed by the DPPH method, using Trolox as a reference substance. All the experiments were performed in duplicate, and results were expressed as mean of gallic acid equivalents (mg GAE/g lyophilized chestnut), mean of rutin equivalents (mg RE/g lyophilized chestnut) and $\mu \mathrm{mol} / \mathrm{L}$ Trolox equivalents/g lyophilized chestnut), respectively.

\subsubsection{Phenolic Compounds Profile by UHPLC-DAD-ESI/MS}

All experiments were performed using an UltiMate 3000 UHPLC system (ThermoFisher Scientific, Bremen, Germany), coupled to a Q Exactive ${ }^{\mathrm{TM}}$ Focus Hybrid Quadrupole-OrbiTrap mass spectrometer) equipped with heated electrospray ionization (HESI) probe (ThermoFisher Scientific). Two chromatographic columns: Accuacore PFP (50 mm $\times 2.1 \mathrm{~mm}, 2.6 \mu \mathrm{m})$ and Accuacore PFP $(100 \mathrm{~mm} \times 2.1 \mathrm{~mm}, 2.6 \mu \mathrm{m})$ from Thermo Fisher Scientific were used for the separation of the compounds, under the gradient elution of a binary solvent system consisting of solvent $\mathrm{A}$ (water with $0.1 \%$ formic acid, $v / v$ ) and solvent $\mathrm{B}$ (methanol with $0.1 \%$ formic acid), at a flow rate of $0.3 \mathrm{~mL} / \mathrm{min}$. The mass spectrometer was operated in negative mode, in a range between $75-1000 \mathrm{~m} / \mathrm{z}$, at a resolution of 70,000. The UHPLC gradient for mass screening and the operation conditions of the mass spectrometer were previously optimized [34]. Calibration solutions consisting of a mixture of caffeine, methionine-arginine phenylalaninealanine-acetate (MRFA), sodium dodecyl sulfate, sodium taurocholate, and Ultramark 1621 were used for the calibration of the Orbitrap mass analyzer.

For phenolic compound quantification, calibration was performed in the concentration range between 0 and $10 \mathrm{mg} / \mathrm{L}$ for each of the phenolic acids and flavonoids by serial dilution with methanol of the stock standard mixture of $100 \mathrm{mg} / \mathrm{L}$ [34]. Analytical performances of the target HRMS analysis of polyphenolic compounds from chestnuts were expressed in terms of linear range, correlation coefficients $\left(R^{2}\right)$, limit of detection (LOD), and limit of quantification (LOQ), and recovery (by spiked experiments $0.5 \mathrm{mg} / \mathrm{L}$ level). The limit of detection (LOD) and the limit of quantification (LOQ) for each target standard compound were determined by the diluted standard solution until the signal-to-noise ratios (S/Ns) were 3:1 and 10:1, respectively. The results were expressed as $\mathrm{mg} / \mathrm{g}$ of lyophilized chestnut sample.

The data were purchased and processed using the Xcalibur software package (Version 4.1). The Total Ion Current (TIC) profile results were found by monitoring the intensity of all the ions produced and acquired in every scan during the chromatographic run. For structural information, data-dependent experiments were performed by acquiring MS/MS spectra of the most intense ions resulting during the HRMS scan event. Normalized collision energy at $30 \%$, a minimum signal threshold at 200, and an isolation width at 3.0 were used. ChemSpider reference spectral database (www.chemspider.com (accessed on 7 February 2022)) was used as a reference library to identify other representative bioactive compounds from the chestnut extracts. For the non-target UHPLC-MS/MS screening, data processing, analysis and interpretation were performed with Compound Discoverer v. 2.1 (Thermo Scientific, San Jose, CA, USA) software using an untargeted metabolomics working template.

\subsubsection{Sugars Profile by HPLC-ELSD}

Chestnut sugar composition in terms of glucose, fructose, sucrose and maltose was determined using an HPLC Surveyor Plus system (Thermo Fischer Scientific Inc., San Jose, CA, USA) using an evaporative light scattering detector (Alltech 3300 ELSD, Grace Davison Discovery Sciences) operated by Chrome Quest software. The chromatographic separation of sugars was achieved using an APS-2-Hypersil amine bonded phase column $(250 \mathrm{~mm} \times 4.6 \mathrm{~mm}, 5 \mu \mathrm{m})$ and isocratic elution of acetonitrile/water $(85: 15, v / v)$ mobile phase at $0.8 \mathrm{~mL} / \mathrm{min}$ flow rate. Chromatographic and ELSD detector parameters were set as described in [36]. The amounts of 
glucose $(\mathrm{G})$, fructose $(\mathrm{F})$, sucrose $(\mathrm{S})$ and maltose $(\mathrm{M})$ in chestnuts were quantified using external calibration curves and the results were expressed as $\mathrm{mg} / \mathrm{g}$ of lyophilized sample.

\subsubsection{Elemental Content Determination}

The determination of the amount of $\mathrm{Ca}, \mathrm{Mg}, \mathrm{Na}, \mathrm{K}, \mathrm{Fe}, \mathrm{Pb}, \mathrm{Ni}, \mathrm{Cu}, \mathrm{Cr}$ in sweet chestnuts fruits of different cultivars was carried out by flame atomic absorption spectroscopy (F-AAS) NOVAA 300 model with an air/acetylene flame. Hallow cathode lamps of the different metals were used as the radiation sources. The analytical measurements were based on time-averaged absorbance. Instrumental parameters were previously presented [37] The digested samples were directly injected into the spectrophotometer. External calibration curves were set up for each of the elements using calibration solutions prepared by successive dilution of standard solutions. All the obtained calibration curves showed very good correlation coefficients $\left(\mathrm{R}^{2}>0.995\right)$ and standard deviation values $<10 \%$. All determinations were performed in duplicates.

\subsection{Data Analysis}

All the analyses were made in duplicate. Statistical differences between different cultivars and harvest years were tested using one way ANOVA followed by Duncan's new multiple range test with a 0.05 significance level. For the ANOVA analysis, the factors taken into consideration in this study were the cultivar and harvest year and the interaction between these factors. A principal component analysis (PCA) and Hierarchical Cluster Analysis were carried out on the data matrix including 20 rows (two repetitions for 10 samples) and 22 phenolic variables resulting from the UHPLC-MS analyses. ANOVA and PCA (including Kaiser-Meyer-Olkin (KMO) measure of sampling adequacy) were performed with statistical software packages Microsoft Excel 2010 (Microsoft Corporation, Redmond, WA, USA) and XLSTAT v. 15.5.03.3707 (Addinsoft, Paris, France).

\section{Results}

It is known that the climatic conditions (e.g., temperature and precipitations), cultivars, geographical area, soil nutrients and water availability may affect the bioactive composition of chestnut fruits [18]. Considering that the samples from this study were obtained in the same climatic and pedological conditions, the differences in the bioactive characteristics, individual phenolic compounds, phytochemical and nutritional profiles, sugar composition and macro- and micro-nutrients can be attributed due to the genetic differences between the studied cultivars or to the differences between the harvest years.

\subsection{Evaluation of Total Polyphenolics (TP), Total Flavonoids (TF) and Antioxidant Activity (AA) of Chestnut Cultivars}

Mean TP, TF and AA values for the studied chestnut cultivars during two consecutive years, 2016 and 2017, investigated in this study and for 2015 reported in a previous study [33] are presented in Figure 1.

High contents of TP correspond to 'Marissard', with average values of $12.69 \mathrm{mg}$ GAE equivalent/g DW, followed by and 'Précoce Migoule', 'Marigoule' and 'Maraval' cultivars with average values of 6.11, 4.84 and $4.1011 \mathrm{mg}$ GAE equivalent/g DW, respectively. The obtained values were in agreement with data from other studies [5]. Average values of TF ranged between $1.57 \mathrm{mg}$ rutin equivalent/g DW in 'Marsol' and $8.64 \mathrm{mg}$ rutin equivalent/g DW in 'Marissard'. Differences between antioxidant activity values, expressed as $\mu$ moli Trolox equivalents/g were observed among the cultivars, with a trend similar to the one observed for TP levels. Good correlation coefficients were obtained between Total Polyphenolics with antioxidant activity $\left(\mathrm{R}^{2}=0.9318\right)$ and between Total Flavonoids with antioxidant activity $\left(\mathrm{R}^{2}=0.9226\right)$ (Figure $\left.\mathrm{S} 1\right)$, suggesting that phenolic compounds were the main antioxidant components of chestnuts. However, determining the contribution of each class of bioactive compounds to total antioxidant activity may be difficult due to the synergistic effect and interaction between different substances [38]. 


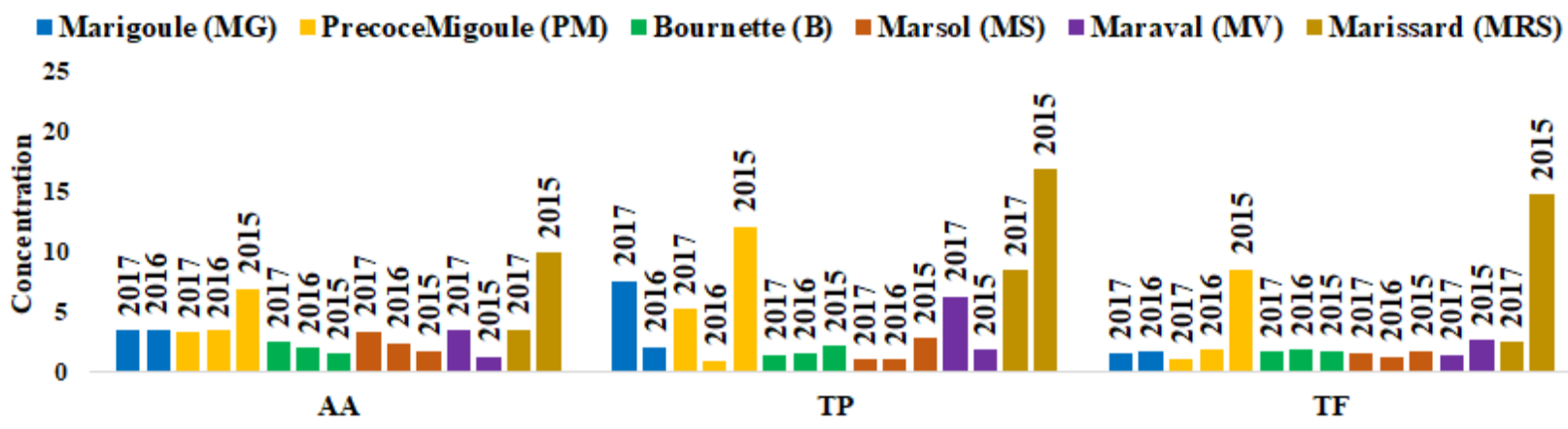

Figure 1. Antioxidant activity (AA) expressed as $\mu$ moli Trolox equivalents/g, Total polyphenols (TP) expressed as mg GAE equivalents/g and Total Flavonoids (TF) expressed as $\mathrm{mg}$ rutin equivalents/g of the six chestnut cultivars for three consecutive years.

According to the Duncan test at $p \leq 0.05$, based on AA, TP and TF, no significant differences were observed between the studied cultivars, only based on AA and TP variables, the 'Marissard', 'Bournette' and 'Marsol' cultivars shows some differences compared to the other cultivars (Figure S2).

For each studied cultivar, variations in TP, TF and AA were observed depending on the harvest year, this being correlated with the climatic conditions specific to each harvest year. It is well known that polyphenols represent important plant metabolites with physiological roles for plant life, which accumulate in plants as a response to stressful conditions, such as harmful environmental conditions (drought, extreme temperatures, pollution, ultraviolet radiations) [39]. Therefore, climatic conditions in the 2015 harvest year were more favorable for obtaining harvest reach in polyphenols, being warmer and drier, compared to 2016 and 2017 (Table 1), the higher TP, TF and AA being obtained for chestnuts fruits harvested in 2015.

Table 1. Climatic data for Râmnicu Vâlcea area during study period (source of data: www.rp5.ru (accessed on 7 February 2022)).

\begin{tabular}{|c|c|c|c|c|c|c|}
\hline \multirow[b]{2}{*}{ Year } & \multicolumn{3}{|c|}{ Temperature at $2 \mathrm{~m}$ Height } & \multirow[b]{2}{*}{$\begin{array}{l}\text { Rainfall } \\
\text { (mm) }\end{array}$} & \multirow[b]{2}{*}{$\begin{array}{c}\text { Relative } \\
\text { Humidity (\%) at } \\
\text { a Height of } 2 \mathrm{~m}\end{array}$} & \multirow[b]{2}{*}{$\begin{array}{c}\text { Number of Days } \\
\text { with Rainfall }\end{array}$} \\
\hline & $\begin{array}{c}\text { Mean } \\
\text { Temperature } \\
\mathrm{T}_{\mathrm{avr},}\left({ }^{\circ} \mathrm{C}\right)\end{array}$ & $\begin{array}{c}\text { Minimum } \\
\text { Temperature } \\
\mathrm{T}_{\text {min }}\left({ }^{\circ} \mathrm{C}\right)\end{array}$ & $\begin{array}{c}\text { Maximum } \\
\text { Temperature } \\
\mathrm{T}_{\max },\left({ }^{\circ} \mathrm{C}\right)\end{array}$ & & & \\
\hline 2015 & 12.6 & -16.1 & 37.3 & 706 & 70 & 126 \\
\hline 2016 & 11.9 & -14.0 & 35.2 & 746 & 73 & 135 \\
\hline 2017 & 12.0 & -19.1 & 38.6 & 802 & 72 & 136 \\
\hline
\end{tabular}

It is important to note that, in order to obtain crops with high phytochemical and nutritional potential, it is necessary for the fruit to reach maturity. Thus, in order to determine the amount of heat or the thermal time necessary to reach the beginning and the end of sweet chestnut harvesting the Growing Degree Hours (GDH) and Growing Degree Days (GDD) were estimated. GDH were calculated from December 1st till start and end of harvesting time the next year, while GDD were calculated from May 1st till the start and end of harvesting time as average hours and, respectively, daily temperatures above $6{ }^{\circ} \mathrm{C}$ (base temperature) and below $30^{\circ} \mathrm{C}$ (highest optimum temperature before stress) [40,41]. The obtained average values (during 2015, 2016 and 2017 harvest years) ranged from 61,832 GDH for 'Précoce Migoule' to 63,670 GDH for 'Maraval', while average values for GDD ranged from $2218^{\circ} \mathrm{D}$ for 'Précoce Migoule' to $2295-2218^{\circ} \mathrm{D}$ for 'Maraval' (Table S1). Our results are consistent with literature data which indicate $60,000 \mathrm{GDH}$ accumulation for the chestnuts located in cooler regions [42] and values between 1900-2400 ${ }^{\circ} \mathrm{D}$ between May to October for chestnut regions [41]. 


\subsection{Target UHPLC-MS/MS Analysis of Phenolic Compounds Biomarkers in the Investigated Chestnut Cultivars}

Target UHPLC-MS/MS method was applied for the quantitative determination of 27 phenolic compounds in the methanolic extracts obtained from fruits of different sweet chestnut cultivars. The peak identification was performed by comparing retention times $\left(t_{R}\right)$ and mass spectra (accurate mass and mass fragments) with those of reference standards (Table S2). Quality performances of the UHPLC-MS/MS method evaluated in terms of linearity, correlation coefficients $\left(\mathrm{R}^{2}\right)$, LODs, LOQs and recovery were detailed in Table S2. The $\mathrm{R}^{2}$ coefficient for all standards was higher than 0.95 , showing good linearity. The values of LODs and LOQs were in the range of $0.12-1.2 \mu \mathrm{g} / \mathrm{g}$ DW and $0.4-4.0 \mu \mathrm{g} / \mathrm{g} \mathrm{DW}$, respectively. The recovery rates of all the components, performed by spiked experiments, ranged from $80 \%$ to $101 \%$. The results demonstrated that the developed UHPLC-MS/MS method was sensitive and accurate for the quantitative determination of all the tested constituents in chestnut fruits. The analyses were conducted in duplicate for each chestnut sample and the data were expressed as mean values and standard deviations for each cultivar harvested in both, 2016 and 2017. The result of the quantification of the target compounds in chestnut extracts were shown in Table 2.

Table 2. The results of the quantitative analysis of phenolic compounds (average values \pm standard deviation) in fruits of different sweet chestnut cultivars harvested in 2016 and 2017 (mg/g DW).

\begin{tabular}{|c|c|c|c|c|c|c|}
\hline Phenolic Compounds & 'Marigoule' (MG) & ‘Précoce Migoule' (PM) & 'Bournette' (B) & 'Marsol' (MS) & 'Maraval' (MV) & $\begin{array}{c}\text { 'Marissard' } \\
\text { (MRS) }\end{array}$ \\
\hline Gallic acid & $1.035 \pm 0.466$ & $0.659 \pm 0.156$ & $1.670 \pm 0.574$ & $0.508 \pm 0.118$ & $0.158 \pm 0.005$ & $1.282 \pm 0.006$ \\
\hline 3,4-Dihydroxybenzoic acid & $0.068 \pm 0.088$ & $0.140 \pm 0.187$ & NF & NF & NF & $0.009 \pm 0.001$ \\
\hline 4-Hydroxybenzoic acid & $0.052 \pm 0.051$ & $0.200 \pm 0.262$ & $0.016 \pm 0.018$ & $0.026 \pm 0.025$ & $0.003 \pm 0.001$ & $0.008 \pm 0.001$ \\
\hline Chlorogenic acid & $0.001 \pm 0.0004$ & $0.001 \pm 0.001$ & NF & $0.002 \pm 0.001$ & NF & $0.001 \pm 0.0009$ \\
\hline Syringic acid & $0.007 \pm 0.008$ & $0.024 \pm 0.012$ & $0.008 \pm 0.010$ & $0.002 \pm 0.003$ & NF & $0.010 \pm 0.001$ \\
\hline Caffeic acid & $0.010 \pm 0.000$ & $0.007 \pm 0.010$ & $0.011 \pm 0.001$ & $0.006 \pm 0.008$ & $0.009 \pm 0.001$ & $0.011 \pm 0.001$ \\
\hline p-Coumaric acid & $0.017 \pm 0.002$ & $0.030 \pm 0.020$ & $0.023 \pm 0.005$ & $0.015 \pm 0.009$ & $0.009 \pm 0.002$ & $0.023 \pm 0.002$ \\
\hline t-Ferulic acid & $0.018 \pm 0.006$ & $0.015 \pm 0.006$ & $0.022 \pm 0.020$ & $0.024 \pm 0.017$ & $0.009 \pm 0.001$ & $0.023 \pm 0.001$ \\
\hline Ellagic acid & $0.757 \pm 0.600$ & $0.349 \pm 0.143$ & $6.211 \pm 6.807$ & $0.217 \pm 0.242$ & $0.056 \pm 0.006$ & $2.902 \pm 0.037$ \\
\hline Cinnamic acid & $0.012 \pm 0.000$ & $0.019 \pm 0.001$ & $0.018 \pm 0.011$ & $0.023 \pm 0.003$ & $0.002 \pm 0.001$ & $0.029 \pm 0.002$ \\
\hline$(+)$-Catechin & $0.332 \pm 0.304$ & $0.258 \pm 0.294$ & $0.090 \pm 0.082$ & $0.036 \pm 0.051$ & $0.174 \pm 0.007$ & $0.363 \pm 0.013$ \\
\hline (-)-Epicatechin & $0.005 \pm 0.004$ & $0.007 \pm 0.008$ & $0.002 \pm 0.002$ & $0.003 \pm 0.003$ & $0.001 \pm 0.001$ & $0.010 \pm 0.001$ \\
\hline Quercetin & $0.006 \pm 0.004$ & $0.005 \pm 0.002$ & $0.001 \pm 0.0002$ & $0.001 \pm 0.001$ & NF & $0.004 \pm 0.001$ \\
\hline Myricetin & $0.044 \pm 0.001$ & $0.044 \pm 0.010$ & $0.042 \pm 0.002$ & $0.038 \pm 0.002$ & $0.031 \pm 0.008$ & $0.045 \pm 0.002$ \\
\hline Naringin & $0.006 \pm 0.004$ & $0.009 \pm 0.012$ & $0.006 \pm 0.002$ & $0.003 \pm 0.001$ & NF & $0.009 \pm 0.001$ \\
\hline Rutin & $0.001 \pm 0.0004$ & $0.004 \pm 0.001$ & $0.004 \pm 0.0002$ & $0.001 \pm 0.0003$ & NF & $0.010 \pm 0.001$ \\
\hline Isorhamnetin & $0.002 \pm 0.002$ & $0.001 \pm 0.0007$ & $0.001 \pm 0.0001$ & NF & NF & $0.001 \pm 0.0010$ \\
\hline Apigenin & NF & NF & NF & NF & NF & NF \\
\hline Hesperidin & NF & NF & NF & NF & NF & NF \\
\hline Kaempferol & NF & NF & NF & NF & NF & NF \\
\hline Pinocembrin & $0.002 \pm 0.0002$ & $<\mathrm{LOQ}$ & $0.002 \pm 0.0002$ & $0.002 \pm 0.0002$ & $<\mathrm{LOQ}$ & $<\mathrm{LOQ}$ \\
\hline Chrysin & $0.001 \pm 0.001$ & NF & NF & NF & NF & NF \\
\hline Galangin & $0.003 \pm 0.003$ & $<\mathrm{LOQ}$ & NF & NF & $<\mathrm{LOQ}$ & NF \\
\hline t-Resveratrol & $0.007 \pm 0.010$ & $0.002 \pm 0.0002$ & $0.001 \pm 0.0003$ & $0.001 \pm 0.0008$ & NF & $0.050 \pm 0.056$ \\
\hline
\end{tabular}

NF-not found.

To evaluate the contribution of each class to the total polyphenolic composition, the phenolic bioactive compounds were grouped in the following classes: benzoic acids (gallic, protocatechuic, p-hydroxybenzoic and syringic acids), cinnamic acids (caffeic, p-coumaric, ferulic, cinnamic and chlorogenic acids), catechins ((+)-catechin and (-)-epicatechin) and flavanols (naringin, rutin, myricetin, quercetin, isorhamnetin, apigenin, pinocembrin) and t-resveratrol) (Figure 2). Apigenin, hesperidin and kaempferol were not identified in chestnut extracts, while chrysin and galangin were quantified in very low amounts only in 'Marigoule' or quantified below LOQs (Table 2).

Within the polyphenolic groups, differences were observed among chestnut cultivar and harvest year, higher amounts of polyphenolic compounds corresponding to 'Marissard', 'Bournette' and 'Précoce Migoule'. 


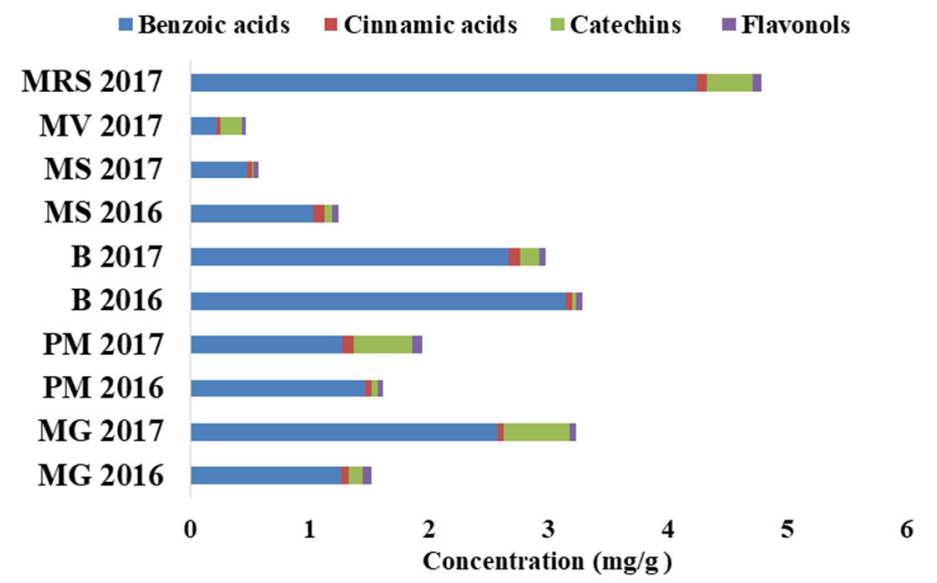

Figure 2. Polyphenolic profile of the analyzed chestnut cultivars harvested in 2016 and 2017.

Benzoic acids and catechins, recognized for their antioxidant, anticancer, antiinflammatory and antimicrobial potential [43], represented the main component of the polyphenolic chestnut extract and among them, gallic and ellagic acids were quantified between $0.162-2.077 \mathrm{mg} / \mathrm{g}$ DW and $0.046-2.928 \mathrm{mg} / \mathrm{g}$ DW, while (+)-catechin was quantified between n.d. and $0.547 \mathrm{mg} / \mathrm{g}$ DW. $\mathrm{p}$-Coumaric, ferulic and cinnamic acids were the representative for the cinnamic acids class, with values between $0.008-0.045 \mathrm{mg} / \mathrm{g} \mathrm{DW}$ for p-coumaric acid, $0.008-0.036 \mathrm{mg} / \mathrm{g}$ DW for ferulic acid and 0.002-0.028 mg/g DW for cinnamic acid. Among flavanols, myricetin, naringin, rutin and quercetin were quantified in higher amounts, with values ranging between $0.036-0.051 \mathrm{mg} / \mathrm{g}$ DW for myricetin, n.d. $-0.018 \mathrm{mg} / \mathrm{g}$ DW for naringin, n.d. $-0.011 \mathrm{mg} / \mathrm{g}$ DW for rutin and n.d. $-0.009 \mathrm{mg} / \mathrm{g}$ DW for quercetin. t-Resveratrol was quantified with values between 0.001 and $0.014 \mathrm{mg} / \mathrm{g}$ DW, with higher amounts in 'Marigoule' and 'Marissard' in the 2017 harvest year. The results of the quantitative analysis are similar to those obtained in other studies [2,5,11].

According to Duncan's test at $p \leq 0.05$, based on individual phenolic compound profiles, no significant differences were observed between the studied cultivars, only some differences can be observed based on gallic and cinnamic acids and rutin variables (Supplementary Figure S3). Based on gallic acid content, 'Bournette' and 'Maraval' are grouped differently compared to the rest of the cultivars, with a high amount of gallic acid corresponding to 'Bournette', while lower quantities corresponded to 'Maraval'. According to cinnamic acid content, 'Marissard' and 'Marsol' were grouped separated toward 'Bournette', which shows lower cinnamic acid content (average value). 'Marissard' displayed the highest rutin content $(0.011 \mathrm{mg} / \mathrm{g} D W)$, being grouped separately from the rest of the chestnut cultivars.

The most important pharmacological properties of gallic and cinnamic acids are attributed to their antioxidant and anti-inflammatory potentials, demonstrating a broad range of beneficial activities, such as antimicrobial, antioxidant, gastroprotective, neuroprotective, cardioprotective, anticancer, antidiabetic and anti-inflammatory [44,45], while rutin shows multiple health-promoting effects, such as neuroprotective, nephroprotective, hepatoprotective, cardioprotective, and retinoprotective activities, but also antibacterial and antifungal activities [46]. Therefore, chestnuts can be considered as valuable natural sources for these bioactive compounds, the phytochemical chestnut extract being suitable for introduction as dietary supplements [47].

For exploratory data analysis purposes, principal components analysis (PCA) and Hierarchical Cluster Analysis (HCA) were used as unsupervised statistical methods in order to discriminate between fruits of different chestnut cultivars, based on the individual phenolic compounds profile. The first two principal components (PC 1 and PC 2) with $54.47 \%$ of the whole variances were extracted from PCA analysis. The other main components that had a minor effect on the model were removed. The obtained low value for the whole variances can be attributed to the small number of samples investigated for 
each category. The distribution in the PC1-PC2 score plot plane of the different chestnut cultivars is sown in Figure 3.

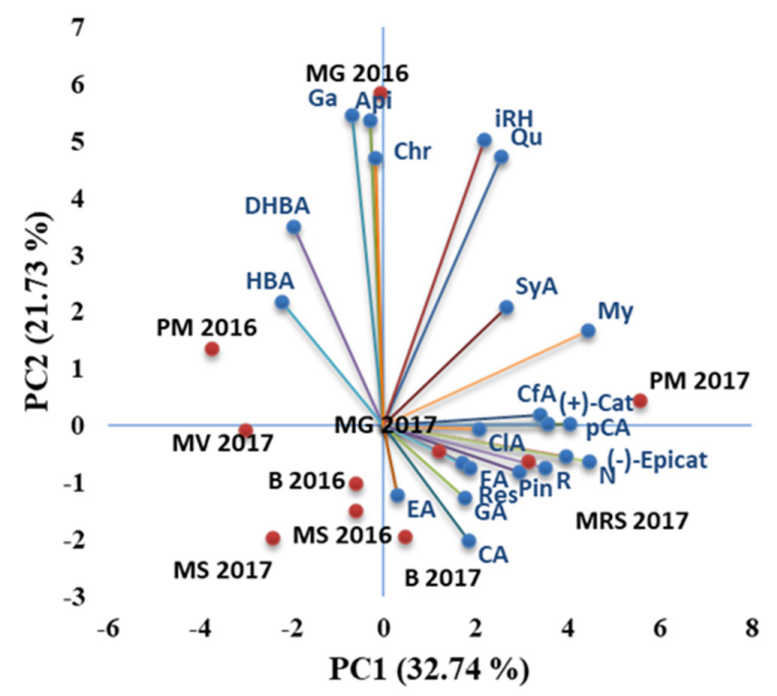

Figure 3. Principal Component Analysis (PCA) of the fruits of different chestnut cultivars based on individual phenolic compounds ('Précoce Migoule'-PM, 'Bournette'-B, 'Marsol'-MS, 'Marissard'-MRS, 'Marigoule'-MG and 'Maraval'—MV).

No clear discrimination can be observed between the fruits of different chestnut cultivars. Along the PC1 axis most cultivars harvested in 2017 can be discriminated, except 'Maraval' and 'Marsol', while the PC2 axis seems to discriminate the 'Précoce Migoule' cultivar from the others. It can be noticed that phenolic compounds, such as gallic, ellagic, cinnamic, chlorogenic and caffeic acids, (+)-catechin and (-)-epicatechin, have the largest contribution to the total variation, along PC1, these compounds being quantified in high amounts in the 2017 harvest year, compared with the 2016 harvest year.

Hierarchical Cluster Analysis was used as an exploratory tool to assess the dissimilarities between the fruits of different chestnut cultivars (Figure 4). At the dissimilarity level of 7, class 1 (C1) refers to 'Précoce Migoule', 'Marsol' and 'Maraval' cultivars, being the cultivars with a lower content of phenolic compounds, compared with the others. Chestnut cultivars with high polyphenolic composition, namely 'Marissard', 'Bournette' and 'Marigoule' were grouped in C2 and C4 groups, while the 'Bournette' cultivar harvested in 2016 forms a distinct group, being the cultivar with lower catechins content.

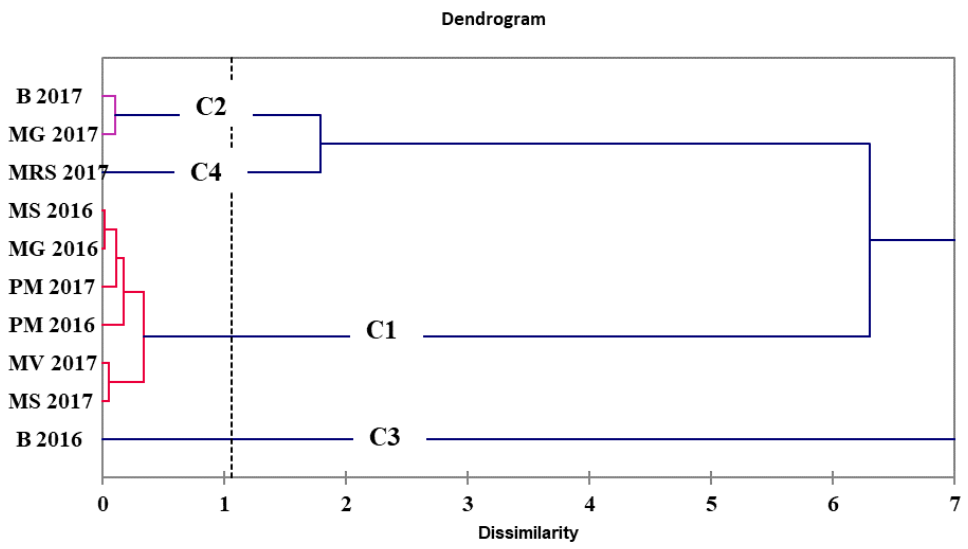

Figure 4. Dendrogram of the fruits of different chestnut cultivars ('Précoce Migoule'-PM, 'Bournette'-B, 'Marsol'-MS, 'Marissard'-MRS, Marigoule-MG and 'Maraval'-MV): C1, C2, C3 and $\mathrm{C} 4$ - classes grouped by dissimilarities criteria. 


\subsection{Untarget UHPLC-MS/MS Analysis of Biomarkers and Their Metabolite Profiles in Fruits of Different Chestnut Cultivars}

Identification and quantification of polyphenols in fruits are of major importance because of their beneficial impact on human health due to their additive and synergistic effects on radical scavenging [48]. Thus, an analytical approach based on a non-target UHPLC-Q-Orbitrap HRMS method was carried out aiming to identify other bioactive compounds and specialized metabolites that occur in methanolic extracts of chestnut fruits, which are responsible for their antioxidant and anti-inflammatory activities, and to highlight the differences between extracts of different chestnut cultivars. Data processing analysis used Compound Discoverer software using an untargeted metabolomics working template, which comprises an untargeted workflow which includes options for peak picking performs RT alignment, prediction of the molecular formula, evaluation of adducts, the assignment and comparison of fragmentation pattern (including dealkylation and dearylation products and bio-transformation products), background annotation, an automated library and database search for identification purposes, including mzCloud $\left(\mathrm{ddMS}^{2}\right)$, Chemspider, MzVault and Mass List Matches [49]. An overview of the Compound Discoverer workflow and parameters can be found in Figure S4. The output of this is a feature list, which includes accurate mass, retention time, $\mathrm{m} / \mathrm{z}$ adducts and their areas and intensities. Only features that were five times the intensity of the blank were considered.

Based on Compound Discoverer processing results, the identity of most of the peaks was attributed. In particular, five main classes of compounds, i.e., phytochemical compounds (flavanols, flavanols, isoflavones, calchones, anthocyanidin derivatives, terpenoids and sesquiterpenoids, vitamins, gibberellin plant hormones, metabolites), fatty acids (saturated and unsaturated fatty acids and derivatives), amino acids, organic acids, but also various sugars and sugar derivatives could be identified in chestnut hydro-methanolic extracts. The compounds name, molecular formula, retention time, exact mass and accurate mass of $\mathrm{m} / \mathrm{z}$ adduct ions, and MS/MS fragment ions in negative ESI mode are shown in Table 3 for bioactive phytochemical compounds, organic acids, amino acids and some metabolites and Table 4 for saturated and unsaturated fatty acids and some derivatives.

Total Ion Current (TIC) and the extracted chromatograms (using a 5 ppm mass accuracy window; negative ion mode, full scan, base peak in the range of $75-1000 \mathrm{~m} / \mathrm{z}$ ) of the main compounds identified in the chestnut methanolic extract were presented in Figure S5 for bioactive phytochemical compounds, Figure S6 for saturated and unsaturated fatty acids and some derivatives, Figure S7 for amino acids and in Figure S8 for gibberellin plant hormones.

The most identified phytochemical compounds were flavonoids, a large group of natural compounds reported in plants, which provide fragrance and taste of the fruits and play an important role for human health due to their high pharmacological activities, mainly attributed to the number of hydroxyl groups attached to base structures of these compounds [50]. Various flavonoids present in the methanolic extract of fruits of different chestnut cultivars have been identified as follows: flavanols (gallocatechin, taxifolin, afzelechin, epiafzelechin) flavanols (luteoforol, dihydrokaempferol, aromadendrin, 3,7-dimethyl quercetin), isoflavones (afromosin (castanin), dihydrogenistein, dalbergioidin, genistein), flavanones (eriodictyol, isoquercetin (quercetin-3-glucoside), quercitrin (quercetin-3-rhamnoside), hyperoside (quercetin-3-galactoside)), chalcones (phloretin and phlorizin) and anthocyanidins derivatives, such as pelargonidin3-O-(6-caffeoyl-beta-Dglucoside) [51]. These compounds are associated with many health benefits to humans associated with their bioactive properties, such as anti-inflammatory, anticancer, anti-aging, cardio-protective, antifungal, antibacterial and antiviral properties [52,53]. 
Table 3. Identification of bioactive phytochemical compounds (flavonoids, chalcones, terpenoids and sesquiterpenoids, gibberellin plant hormones), organic acids, amino acids and some nucleosides in chestnut extract by UHPLC-Q-Exactive high-accuracy analysis of deprotonated precursors and fragment ions of specific components combined with data processing using Compound Discoverer software.

\begin{tabular}{|c|c|c|c|c|c|c|}
\hline Compound Name & Formula & R.T. (min) & Exact Mass & $\begin{array}{c}\text { Accurate Mass } \\
{[\mathbf{M}-\mathbf{H}]}\end{array}$ & $\begin{array}{c}\text { Experimental } \\
\text { Adduct Ion }(\mathrm{m} / \mathrm{z})\end{array}$ & MS $^{2}$ Fragments $(\mathrm{m} / \mathrm{z})$ \\
\hline \multicolumn{7}{|c|}{ Phytochemical Compounds } \\
\hline \multicolumn{7}{|c|}{ Flavonoids } \\
\hline (+)-gallocatechin & $\mathrm{C}_{15} \mathrm{H}_{14} \mathrm{O}_{7}$ & 5.72 & 306.0740 & 305.0667 & 305.0668 & $\begin{array}{c}109.0295,124.016 \\
125.0249,137.0248 \\
139.0400\end{array}$ \\
\hline $\begin{array}{l}(+) \text {-taxifolin } /(-)- \\
\text { taxifolin }\end{array}$ & $\mathrm{C}_{15} \mathrm{H}_{12} \mathrm{O}_{7}$ & $7.44 / 8.37$ & 304.0583 & 303.0510 & 303.0510 & $\begin{array}{c}273.0412,125.0241 \\
259.0611,178.9977 \\
151.0028\end{array}$ \\
\hline $\begin{array}{l}\text { afzelechin/(-)- } \\
\text { epiafzelechin }\end{array}$ & $\mathrm{C}_{15} \mathrm{H}_{14} \mathrm{O}_{5}$ & $11.40 / 8.67$ & 274.0841 & 273.0769 & 273.0770 & $\begin{array}{c}\text { 229.0867; 205.0864; } \\
\text { 187.0758; 166.02628; } \\
137.02335 ; 97.02821\end{array}$ \\
\hline $\begin{array}{l}(-)- \\
\text { dihydrokaempferol/(+)- } \\
\text { (aromadendrin) }\end{array}$ & $\mathrm{C}_{15} \mathrm{H}_{12} \mathrm{O}_{6}$ & $8.09 / 9.55$ & 288.0634 & 287.0561 & 287.0562 & $\begin{array}{c}259.0618 ; 243.0665 ; \\
201.0554 ; 151.0034 ; \\
125.0242 \\
\end{array}$ \\
\hline $\begin{array}{l}\text { 3,7-dimethyl } \\
\text { quercetin }\end{array}$ & $\mathrm{C}_{17} \mathrm{H}_{14} \mathrm{O}_{7}$ & 12.21 & 330.0740 & 329.0667 & 329.0668 & $\begin{array}{c}\text { 314.03860; 299.01480; } \\
\text { 285.0354; 271.02044; } \\
\text { 243.0267 }\end{array}$ \\
\hline afromosin (castanin) & $\mathrm{C}_{17} \mathrm{H}_{14} \mathrm{O}_{5}$ & 11.35 & 298.0841 & 297.0769 & 297.0769 & $\begin{array}{c}282.05362 ; 283.06802 ; \\
267.03021 ; 253.04797 ; \\
167.04965\end{array}$ \\
\hline dihydro genistein & $\mathrm{C}_{15} \mathrm{H}_{12} \mathrm{O}_{5}$ & 10.57 & 272.0685 & 271.0612 & 271.0613 & $\begin{array}{c}\text { 209.0559; 177.0117; } \\
\text { 151.0017; 119.0505; } \\
\text { 93.0336 }\end{array}$ \\
\hline $\begin{array}{c}(+,-)- \\
\text { dalbergioidin/eriodictyol }\end{array}$ & $\mathrm{C}_{15} \mathrm{H}_{12} \mathrm{O}_{6}$ & $8.08 / 9.54$ & 288.0634 & 287.0561 & 287.0562 & $\begin{array}{c}135.0757 ; 151.0350 ; \\
255.0274 ; 287.0719 ; \\
227.0318\end{array}$ \\
\hline genistein & $\mathrm{C}_{15} \mathrm{H}_{10} \mathrm{O}_{5}$ & 12.61 & 270.05282 & 269.0456 & 269.0457 & $\begin{array}{c}\text { 159.04420; 133.02835; } \\
\text { 201.05527; 181.06546; } \\
\text { 107.01257 }\end{array}$ \\
\hline $\begin{array}{l}\text { isoquercetin } \\
\text { (quercetin-3- } \\
\text { glucoside) }\end{array}$ & $\mathrm{C}_{21} \mathrm{H}_{20} \mathrm{O}_{12}$ & 7.72 & 464.0954 & 463.0881 & 463.0883 & $\begin{array}{l}\text { 300.02771; 355.02985; } \\
\text { 271.02491; 243.02969; } \\
\text { 178.99773; 151.00262 }\end{array}$ \\
\hline $\begin{array}{l}\text { quercitrin (quercetin- } \\
\text { 3-rhamnoside) }\end{array}$ & $\mathrm{C}_{21} \mathrm{H}_{20} \mathrm{O}_{11}$ & 8.40 & 448.1005 & 447.0932 & 447.0933 & $\begin{array}{l}\text { 151.0051; 179.0007; } \\
\text { 243.0323; 271.0276; } \\
\text { 301.03852; 284.0353 }\end{array}$ \\
\hline $\begin{array}{l}\text { hyperoside (quercetin- } \\
\text { 3-galactoside) }\end{array}$ & $\mathrm{C}_{21} \mathrm{H}_{20} \mathrm{O}_{12}$ & 8.68 & 464.0954 & 463.0881 & 463.0887 & $\begin{array}{l}\text { 300.02771; 355.02985; } \\
\text { 271.02491; 243.02969; } \\
\text { 178.99773; 151.00262 }\end{array}$ \\
\hline $\begin{array}{l}\text { Pelargonidin } \\
\text { 3-O-(6-caffeoyl-beta- } \\
\text { D-glucoside) }\end{array}$ & $\mathrm{C}_{30} \mathrm{H}_{26} \mathrm{O}_{13}$ & 5.60 & 594.13734 & 593.1301 & 593.1304 & $\begin{array}{l}\text { 145.0282; 255.0293; } \\
284.0313 ; 285.0390\end{array}$ \\
\hline phloretin & $\mathrm{C}_{15} \mathrm{H}_{14} \mathrm{O}_{5}$ & 11.40 & 274.0841 & 273.0769 & 273.0770 & $\begin{array}{c}\text { 179.03509; 167.03498; } \\
125.0244 ; 123.04515\end{array}$ \\
\hline phlorizin & $\mathrm{C}_{21} \mathrm{H}_{24} \mathrm{O}_{10}$ & 8.69 & 436.1370 & 435.1297 & 435.1298 & $\begin{array}{l}\text { 167.0459; 273.0846; } \\
\text { 274.0563; 122.0333; }\end{array}$ \\
\hline
\end{tabular}


Table 3. Cont.

\begin{tabular}{|c|c|c|c|c|c|c|}
\hline Compound Name & Formula & R.T. (min) & Exact Mass & $\begin{array}{c}\text { Accurate Mass } \\
{[\mathbf{M}-\mathbf{H}]}\end{array}$ & $\begin{array}{c}\text { Experimental } \\
\text { Adduct Ion }(\mathrm{m} / \mathrm{z})\end{array}$ & MS $^{2}$ Fragments $(\mathrm{m} / \mathrm{z})$ \\
\hline \multicolumn{7}{|c|}{ Other Phytochemical Compounds } \\
\hline Gingerol & $\mathrm{C}_{17} \mathrm{H}_{26} \mathrm{O}_{4}$ & 15.71 & 294.1831 & 293.1759 & 293.1791 & $\begin{array}{c}\text { 178.0657; 193.0906; } \\
99.0809 ; 293.1751 ; \\
137.0009\end{array}$ \\
\hline $\begin{array}{c}5- \\
\text { hydroxyconiferylalcohol }\end{array}$ & $\mathrm{C}_{10} \mathrm{H}_{12} \mathrm{O}_{4}$ & 7.45 & 196.0736 & 195.0663 & 195.0665 & $\begin{array}{c}195.0665 ; 179.0665 ; \\
193.0657\end{array}$ \\
\hline azelaic acid & $\mathrm{C}_{9} \mathrm{H}_{16} \mathrm{O}_{4}$ & 7.64 & 188.1049 & 187.0976 & 187.0967 & $\begin{array}{c}\text { 97.1001; 123.1002; } \\
125.1008\end{array}$ \\
\hline $\begin{array}{l}\text { Dihydro caffeic acid/ } \\
\text { hydroxyphenyl lactic } \\
\text { acid }\end{array}$ & $\mathrm{C}_{9} \mathrm{H}_{10} \mathrm{O}_{4}$ & $5.42 / 5.88$ & 182.0579 & 181.0507 & 181.0498 & $\begin{array}{c}\text { 59.0001; 109.3005; } \\
\text { 118.9004; 121.1001; } \\
\text { 135.3025; }\end{array}$ \\
\hline $\begin{array}{c}\text { 3,4- } \\
\text { dihydroxymandelate }\end{array}$ & $\mathrm{C}_{8} \mathrm{H}_{8} \mathrm{O}_{5}$ & 6.32 & 184.0372 & 183.0299 & 183.0290 & $\begin{array}{c}\text { 137.0242; 139.0401; } \\
\text { 183.0294; }\end{array}$ \\
\hline cucurbitacin F & $\mathrm{C}_{30} \mathrm{H}_{46} \mathrm{O}_{7}$ & 12.00 & 518.3244 & 517.3171 & 517.3170 & $\begin{array}{c}\text { 517.3170; } 499.3065 ; \\
385.2386\end{array}$ \\
\hline $\begin{array}{l}\text { ursolic and oleanolic } \\
\text { acids }\end{array}$ & $\mathrm{C}_{30} \mathrm{H}_{48} \mathrm{O}_{3}$ & 16.10 & 456.3604 & 455.3531 & 455.3531 & $455.3521 ; 456.3550$ \\
\hline (S)-abscisic acid & $\mathrm{C}_{15} \mathrm{H}_{20} \mathrm{O}_{4}$ & 8.13 & 264.1362 & 263.1289 & 263.1289 & $\begin{array}{l}\text { 152.8462; 219.6015; } \\
\text { 203.8293; 263.0201 }\end{array}$ \\
\hline geranyl acetate & $\mathrm{C}_{12} \mathrm{H}_{20} \mathrm{O}_{2}$ & 11.15 & 196.1463 & 195.1391 & 195.1384 & $\begin{array}{l}\text { 1195.1384; 136.1387; } \\
\text { 121.2860; } 93.2864\end{array}$ \\
\hline Sebacic acid & $\mathrm{C}_{10} \mathrm{H}_{18} \mathrm{O}_{4}$ & 8.47 & 202.1205 & 201.1133 & 201.1124 & $\begin{array}{l}\text { 110.9001; 139.1134; } \\
\text { 183.1038; 201.1127; }\end{array}$ \\
\hline \multicolumn{7}{|c|}{ Gibberellin Compounds-Plant Hormones (Phytohormones) } \\
\hline $\begin{array}{c}\text { gibberellin } \\
\text { A2-O-beta-D-glucoside }\end{array}$ & $\mathrm{C}_{25} \mathrm{H}_{34} \mathrm{O}_{11}$ & 8.43 & 510.2101 & 509.2029 & 509.2029 & $328.2029,179.2541$ \\
\hline gibberellin A8 & $\mathrm{C}_{19} \mathrm{H}_{24} \mathrm{O}_{7}$ & 8.86 & 364.1522 & 363.1449 & 363.1450 & $\begin{array}{c}\text { 275.0321; 118.6022; } \\
\text { 160.6709; }\end{array}$ \\
\hline $\begin{array}{c}\text { gibberellin } \\
\text { A19/gibberellin A36 }\end{array}$ & $\mathrm{C}_{20} \mathrm{H}_{26} \mathrm{O}_{6}$ & $12.08 / 15.71$ & 362.1729 & 361.1657 & 361.1666 & $\begin{array}{l}\text { 203.1055; 229.1291; } \\
\text { 273.0125; 360.8283 }\end{array}$ \\
\hline $\begin{array}{c}\text { gibberellin } \\
\text { A53/gibberellin A14 }\end{array}$ & $\mathrm{C}_{20} \mathrm{H}_{28} \mathrm{O}_{5}$ & $10.36 / 10.74$ & 348.1937 & 347.1864 & $\begin{array}{l}347.1862 / \\
347.1864\end{array}$ & $\begin{array}{c}\text { 189.0372; 329.0731; } \\
\text { 347.2285;/ } \\
303.1956 ; 347.1837\end{array}$ \\
\hline $\begin{array}{c}\text { gibberellin A1 } \\
\text { (gibberellic } \\
\text { acid)/gibberellin } \\
\text { A29/gibberellin A34 }\end{array}$ & $\mathrm{C}_{19} \mathrm{H}_{24} \mathrm{O}_{6}$ & $7.80 / 8.91 / 9.23$ & 348.1573 & 347.1500 & $\begin{array}{l}347.1500 / \\
347.1499 \\
347.1501\end{array}$ & $\begin{array}{c}228.5631 ; 229.2383 ; \\
273.1972 ; / \\
259.3782 ; 303.0891 ; \\
347.0805 ; /\end{array}$ \\
\hline gibberellin A3 & $\mathrm{C}_{19} \mathrm{H}_{22} \mathrm{O}_{6}$ & 7.35 & 346.1416 & 345.1338 & 345.1344 & $\begin{array}{c}\text { 71.0489; } 143.0855 \\
221.1330\end{array}$ \\
\hline Gibberellin A12 & $\mathrm{C}_{20} \mathrm{H}_{28} \mathrm{O}_{4}$ & 10.01 & 332.1988 & 331.1915 & 331.1914 & $\begin{array}{c}241.1956 ; 259.2058 ; \\
287.2003\end{array}$ \\
\hline \multicolumn{7}{|c|}{ Organic Acids } \\
\hline Quinic acid & $\mathrm{C}_{7} \mathrm{H}_{12} \mathrm{O}_{6}$ & 3.41 & 192.0634 & 191.0561 & 191.0553 & $\begin{array}{c}\text { 85.0301; 93.0035; } \\
127.0001 ; 191.0556\end{array}$ \\
\hline Citric acid & $\mathrm{C}_{6} \mathrm{H}_{8} \mathrm{O}_{7}$ & 2.14 & 192.027 & 191.0197 & 191.0188 & $\begin{array}{l}\text { 173.0091; 129.0193; } \\
\text { 111.0088; 87.00877 }\end{array}$ \\
\hline Malic acid & $\mathrm{C}_{4} \mathrm{H}_{6} \mathrm{O}_{5}$ & 1.47 & 134.0215 & 133.0142 & 133.0130 & $\begin{array}{c}\text { 133.0142; } 115.0036 ; \\
89.0244 ; 71.0138\end{array}$ \\
\hline
\end{tabular}


Table 3. Cont.

\begin{tabular}{|c|c|c|c|c|c|c|}
\hline Compound Name & Formula & R.T. (min) & Exact Mass & $\begin{array}{c}\text { Accurate Mass } \\
{[\mathbf{M}-\mathbf{H}]}\end{array}$ & $\begin{array}{c}\text { Experimental } \\
\text { Adduct Ion }(\mathrm{m} / \mathrm{z})\end{array}$ & $\mathrm{MS}^{2}$ Fragments $(\mathrm{m} / \mathrm{z})$ \\
\hline \multicolumn{7}{|c|}{ Amino Acids } \\
\hline $\begin{array}{l}N \text {-acetyl } \\
\text { tryptophan }\end{array}$ & $\mathrm{C}_{13} \mathrm{H}_{14} \mathrm{~N}_{2} \mathrm{O}_{3}$ & 7.43 & 246.1004 & 245.0932 & 245.0929 & $202.0929,159.0926$ \\
\hline $\begin{array}{l}N \text {-Acetyl-L- } \\
\text { tyrosine }\end{array}$ & $\mathrm{C}_{11} \mathrm{H}_{13} \mathrm{NO}_{4}$ & 6.03 & 223.0845 & 222.0772 & 222.0768 & $179.0772,136.1912$ \\
\hline $\begin{array}{c}N \text {-Acetyl-L- } \\
\text { phenylalanine }\end{array}$ & $\mathrm{C}_{11} \mathrm{H}_{13} \mathrm{NO}_{3}$ & 6.86 & 207.0895 & 206.0823 & 206.0815 & $\begin{array}{l}\text { 91.1012; 103.0024; } \\
\text { 147.2015;164.2021; }\end{array}$ \\
\hline $\begin{array}{l}\text { L-Tyrosine methyl } \\
\text { ester }\end{array}$ & $\mathrm{C}_{10} \mathrm{H}_{13} \mathrm{NO}_{3}$ & 13.49 & 195.0895 & 194.0823 & 194.0815 & $133.0657 ; 194.0817$ \\
\hline D-Tryptophan & $\mathrm{C}_{11} \mathrm{H}_{12} \mathrm{~N}_{2} \mathrm{O}_{2}$ & 6.26 & 204.0899 & 203.0826 & 203.0820 & $158.0820,130.0820$ \\
\hline L-Tryptophan & $\mathrm{C}_{11} \mathrm{H}_{12} \mathrm{~N}_{2} \mathrm{O}_{2}$ & 7.42 & 204.0899 & 203.0826 & 203.0820 & $\begin{array}{c}74.0255 ; 116.0504 ; \\
142.0658 ; 159.0926 \\
203.0821\end{array}$ \\
\hline D-Tyrosine & $\mathrm{C}_{9} \mathrm{H}_{11} \mathrm{NO}_{3}$ & 2.55 & 181.0739 & 180.0666 & 180.0658 & $\begin{array}{c}119.0498 ; 163.0387 \\
180.0684\end{array}$ \\
\hline L-Glutamic acid & $\mathrm{C}_{5} \mathrm{H}_{9} \mathrm{NO}_{4}$ & 1.26 & 147.0532 & 146.0459 & 146.0466 & 102.0559; 128.0353; \\
\hline \multicolumn{7}{|c|}{ Other bioactive compounds/metabolites } \\
\hline $\begin{array}{l}\text { Pantothenic acid } \\
\text { (Vitamin B5) }\end{array}$ & $\mathrm{C}_{9} \mathrm{H}_{17} \mathrm{NO}_{5}$ & 4.97 & 219.1107 & 218.1034 & 218.1028 & $\begin{array}{c}\text { 71.0512; 88.0407; } \\
\text { 146.0816; 218.1029; }\end{array}$ \\
\hline vitamin C & $\mathrm{C}_{6} \mathrm{H}_{8} \mathrm{O}_{6}$ & 2.64 & 176.0321 & 175.0248 & 175.0238 & $\begin{array}{c}\text { 127.0036; } 115.0037 \\
\text { 87.0087; } 59.0138\end{array}$ \\
\hline Uridine & $\mathrm{C}_{9} \mathrm{H}_{12} \mathrm{~N}_{2} \mathrm{O}_{6}$ & 2.44 & 244.0695 & 243.0623 & 243.0619 & $\begin{array}{c}\text { 109.9196; 200.0670; } \\
\text { 140.0354; 152.0355; } \\
\text { 243.0621; }\end{array}$ \\
\hline Thymidine & $\mathrm{C}_{10} \mathrm{H}_{14} \mathrm{~N}_{2} \mathrm{O}_{5}$ & 5.16 & 242.0903 & 241.0830 & 241.0828 & $\begin{array}{r}\text { 42.2001; 124.9002; } \\
\text { 151.0504; 241.0822; }\end{array}$ \\
\hline Guanosine & $\mathrm{C}_{10} \mathrm{H}_{13} \mathrm{~N}_{5} \mathrm{O}_{5}$ & 4.18 & 283.0917 & 282.0844 & 282.0845 & $\begin{array}{l}\text { 108.0201; 133.0154; } \\
\text { 150.0421; 282.0844; }\end{array}$ \\
\hline
\end{tabular}

Other phytochemical compounds identified in the chestnut extract are phenol phytochemical, such as gingerol and dihydro caffeic acid with anticancer, anti-inflammatory, anti-fungal, antioxidant, neuroprotective and gastro-protective properties [54], carboxylic acids, such as sebacic and azaleic acids used to treat mild to moderate acne [55] and 3,4-dihydroxymandelate, a compound with a powerful antioxidative potential present in some fruits [56]. Some triterpenes and sesquiterpenes were also identified, among them cucurbitacin F which presents cytotoxic properties [57], ursolic and oleanolic acids with numerous beneficial effects, including anti-oxidative, anti-inflammatory, anticancer and neuroprotective potential [58], abscisic acid, a plant hormone that plays an important role in managing glucose homeostasis in humans [59] and geranyl acetate, a plant metabolite with anti-inflammatory properties [60].

Gibberellin plant hormones represent tetracyclic diterpene acids with significant agricultural importance in plants, regulating seed germination, root and shoot elongation, flowering, and fruit patterning [61]. Of the more than $130 \mathrm{GAs}$ identified so far in plants, fungi and bacteria, gibberellic acid (GA1), GA3, GA4, and GA7 shows bioactive properties, being used as endogenous regulators of plant growth and development [62]. In chestnut extracts were identified bioactive gibberellin GA1 and GA3 which shows antimicrobial properties against phytopathogens and clinical pathogens, thus being a powerful tool for antimicrobial resistance to conventional antibiotics [63], but also other gibberellins, such as GA8, GA12, GA14, GA19, GA29, GA34, GA36, GA53.

Amino acids are essential elements in the synthesis of proteins in the body and help meet the body's needs for growth and health [64]. Regarding amino acids, essential amino acids, such as tryptophan (Trp) and some derivatives like $\mathrm{N}$-acetyl tryptophan (AcTrp) 
or N-Acetyl-L-phenylalanine (AcPhe) derived from phenylalanine (Phe) were identified in chestnut extracts. These amino acids are precursors for neurotransmitters, such as serotonin, dopamine, norepinephrine (noradrenaline), epinephrine (adrenaline), but also for the skin pigment melanin [65,66]. In addition, some non-essential amino acids, such as glutamic acid (Glu) and tyrosine (Tyr) and some derivatives like N-Acetyl-L-tyrosine (AcTyr) and L-Tyrosine methyl ester (TyMeE) were identified in chestnut extracts, these amino acids representing excitatory neurotransmitters, glutamic acid being the precursor for the synthesis of the inhibitory gamma-aminobutyric acid (GABA) in neurons [67], while tyrosine is also involved in the synthesis of the neurotransmitter dopamine which is converted to catecholamines, such as norepinephrine (noradrenaline) and epinephrine (adrenaline) [68]. Therefore, it can be concluded that chestnut fruits and derived food supplements and functional foods represent very good support for the health of the nervous system and skin.

Essential organic acids for human metabolism, such as citric and malic acids [28] were identified in the extracts of the studied chestnut cultivars, indicating that chestnuts represent a potential source of citric acid which shows antioxidant and anti-inflammatory properties and can prove support for neurodegenerative diseases [69] and malic acid which shows skin-care benefits, improving of physical performance, cardiac function, and control of kidney stones and fibromyalgia [70]. Additionally, quinic acid which represents the starting material for the synthesis of different pharmaceuticals [71] was identified in chestnut extracts.

\section{Vitamins}

Other bioactive compounds identified in the chestnut extracts are vitamins, such as pantothenic acid (vitamin B5) which is essential for the release of energy from food, for healthy growth and for the production of antibodies and vitamin $C$ which is an essential nutrient in many multicellular organisms, especially in humans [72], but also some nucleosides, such as uridine, thymidine and guanosine which were correlated with numerous physiological processes in the body and showed antioxidant and antitumor activities [73].

Statistical analysis based on the qualitative data relating to phytochemical (flavonoids, triterpene, phytohormones) and nutritional (amino acids, organic acids, vitamins, nucleosides) UHPLC-MS/MS fingerprints of fruits of different chestnut cultivars harvested in two years was performed in order to discriminate between the chestnut cultivars. As shown in Figure 5a, a clear discrimination can be observed between the fruit of chestnut cultivars harvested in the 2017 harvest year from those harvested in the 2016 year, indicating that climatic conditions (temperature, water availability) play an essential role in the synthesis of fruit phytochemicals and nutrients.

As harvest year plays a crucial role in the synthesis of fruit phytochemicals and nutrients, Hierarchical Cluster Analysis was used as an exploratory tool to assess the dissimilarities between the fruits of different chestnut cultivars harvested in the same year, for example, 2017 (Figure 5b). As observed, fruits of 'Marigoule' and 'Marissard' were grouped separated from the other cultivars, while 'Marsol', 'Bournette' and 'Précoce Migoule' form another group which is clustered separately from 'Maraval'.

Untarget UHPLC-MS/MS analysis coupled with Compound Discoverer processing of the data and Lipid Data Analyzer 2.6, only 10 fatty acids were detected in the studied chestnut cultivars, including five types of saturated fatty acids (lignoceric acid, phytanic acid, stearic acid, palmitic acid and behenic acid) and five types of unsaturated fatty acids (eicosanoic acid, oleic acid, linolenic acid, farnesoic acid and pinellic acid) (Table 4).

Palmitic acid is the most abundant saturated fatty acid in chestnuts, while the unsaturated fatty acids in chestnuts are mainly represented by oleic acid, linoleic acid and $\alpha$-linolenic acid [64]. 
Table 4. Identification of fatty acids and some derivatives in chestnut extract by UHPLC-Q-Exactive high-accuracy analysis of deprotonated precursors and fragment ions of specific components combined with data processing using Compound Discoverer software.

\begin{tabular}{|c|c|c|c|c|c|c|}
\hline Compound Name & Formula & R.T. (min) & Exact Mass & $\begin{array}{l}\text { Accurate Mass } \\
{[\mathbf{M}-\mathbf{H}]^{-}}\end{array}$ & $\begin{array}{c}\text { Experimental } \\
\text { Adduct Ion }(\mathrm{m} / \mathrm{z})\end{array}$ & MS $^{2}$ Fragments (m/z) \\
\hline \multicolumn{7}{|c|}{ Saturated Fatty Acids and Derivates } \\
\hline Lignoceric acid & $\mathrm{C}_{24} \mathrm{H}_{48} \mathrm{O}_{2}$ & 18.86 & 368.3654 & 367.3582 & 367.3582 & $367.3590 ; 368.3625$ \\
\hline Phytanic acid & $\mathrm{C}_{20} \mathrm{H}_{40} \mathrm{O}_{2}$ & 17.12 & 312.3028 & 311.2956 & 311.2956 & $311.2956,267.2956$ \\
\hline Stearic acid (Octadecanoic acid) & $\mathrm{C}_{18} \mathrm{H}_{36} \mathrm{O}_{2}$ & 17.32 & 284.2715 & 283.2643 & 283.2642 & 283.2636 \\
\hline Palmitic acid (Hexadecanoic acid) & $\mathrm{C}_{16} \mathrm{H}_{32} \mathrm{O}_{2}$ & 16.59 & 256.2402 & 255.2330 & 255.2327 & 255.2317; 256.2350; 237.3001; \\
\hline Behenic acid (Docosanoicacid) & $\mathrm{C}_{22} \mathrm{H}_{44} \mathrm{O}_{2}$ & 18.40 & 340.3341 & 339.3269 & 339.3267 & $339.3265 ; 340.3303$ \\
\hline $\begin{array}{l}\text { Dioxo-hydrox(6,9-dioxo-(11R,15S)- } \\
\text { dihydroxy-13E-prostenoic acid } \\
\text { (6-keto PGE1) }\end{array}$ & $\mathrm{C}_{20} \mathrm{H}_{32} \mathrm{O}_{6}$ & 7.72 & 368.2199 & 367.2126 & 367.2125 & $\begin{array}{c}\text { 143.2541; } 205.5478 ; 124.3256 ; \\
\text { 269.3254;187.1475; }\end{array}$ \\
\hline \multicolumn{7}{|c|}{ Unsaturated Fatty Acids and Derivates } \\
\hline Eicosanoic acid (Arachidic acid) & $\mathrm{C}_{20} \mathrm{H}_{40} \mathrm{O}_{2}$ & 17.92 & 312.3028 & 311.2956 & 311.2956 & 311.2956 \\
\hline Oleic acid & $\mathrm{C}_{18} \mathrm{H}_{34} \mathrm{O}_{2}$ & 16.79 & 282.2559 & 281.2486 & 281.2484 & $263.3001 ; 281.2474$ \\
\hline Linolenic acid & $\mathrm{C}_{18} \mathrm{H}_{30} \mathrm{O}_{2}$ & 15.88 & 278.2246 & 277.2173 & 277.2172 & $233.2001 ; 259.2002 ; 277.2188$ \\
\hline Farnesoic acid & $\mathrm{C}_{15} \mathrm{H}_{24} \mathrm{O}_{2}$ & 12.32 & 236.1776 & 235.1704 & 235.1701 & $235.1701,191.1704$ \\
\hline Pinellic acid & $\mathrm{C}_{18} \mathrm{H}_{34} \mathrm{O}_{5}$ & 10.18 & 330.2406 & 329.2334 & 329.2332 & $329.2332,285.2332$ \\
\hline $\begin{array}{l}\text { 9Z,11E-octadecadienoic acid } \\
\text { (9Z, 11E-Linoleic acid) }\end{array}$ & $\mathrm{C}_{18} \mathrm{H}_{32} \mathrm{O}_{2}$ & 16.30 & 280.2402 & 279.2330 & 279.2328 & $279.2324 ; 234.2328$ \\
\hline (9S,10S)-9,10-Dihydroxyoctadecanoate & $\mathrm{C}_{18} \mathrm{H}_{36} \mathrm{O}_{4}$ & 13.69 & 316.2614 & 315.2541 & 315.2540 & $315.2540,271.2541$ \\
\hline $\begin{array}{l}\text { 9,10-dihydroxy-12Z-octadecenoic acid } \\
\text { (9,10-DiHOME)/ } \\
\text { 12,13-dihydroxy-9Z-octadecenoic acid }\end{array}$ & $\mathrm{C}_{18} \mathrm{H}_{34} \mathrm{O}_{4}$ & $\begin{array}{l}12.89 / \\
12.41\end{array}$ & 314.2457 & 313.2385 & $\begin{array}{l}313.2385 / \\
313.2386\end{array}$ & 171.1081; 201.0922; 277.1702; \\
\hline $\begin{array}{l}\text { 2-Hydroperoxy-2,4-octadecadienoic acid/ } \\
\text { 8R-hydroperoxy-9Z,12Z-octadecadienoic } \\
\text { acid (8-HpODE)/ } \\
\text { 13S-hydroperoxy-9Z,11E-octadecadienoic } \\
\text { acid (13-HpODE)/ } \\
\text { 11S-hydroperoxy-9Z,12Z-octadecadienoic } \\
\text { acid (11S-HpODE) }\end{array}$ & $\mathrm{C}_{18} \mathrm{H}_{32} \mathrm{O}_{4}$ & $\begin{array}{l}13.02 / \\
13.32 / \\
13.49 / \\
12.73\end{array}$ & 312.3028 & 311.2228 & $\begin{array}{l}311.2228 / \\
311.2228 / \\
311.2229 / \\
311.2230\end{array}$ & 223.1041; 205.0112; 211.1208; \\
\hline 11Z-eicosenoic acid (Gondoic acid)/ & $\mathrm{C}_{20} \mathrm{H}_{38} \mathrm{O}_{2}$ & 17.46 & 310.2872 & 309.2799 & 309.2800 & 309.2794 \\
\hline $\begin{array}{c}\text { 9S-hydroperoxy-10E,12Z,15Z- } \\
\text { octadecatrienoic acid (9S HpOTrE)/ } \\
\text { 13S-hydroperoxy-9Z,11E,15Z- } \\
\text { octadecatrienoic } \\
\text { acid(13(S)-HpOTrE) }\end{array}$ & $\mathrm{C}_{18} \mathrm{H}_{30} \mathrm{O}_{4}$ & $\begin{array}{l}12.11 / \\
12.62\end{array}$ & 310.2144 & 309.2072 & $\begin{array}{l}309.2073 / \\
309.2073\end{array}$ & $\begin{array}{c}\text { 139.0400; 190.1600; 209.1491; } \\
\text { 227.1602; 252.0801; }\end{array}$ \\
\hline 2-Oxooctadecanoic acid (2-oxostearic acid) & $\mathrm{C}_{18} \mathrm{H}_{34} \mathrm{O}_{3}$ & 14.51 & 298.2508 & 297.2435 & 297.2433 & 297.2433 \\
\hline $\begin{array}{c}\text { 12R,13S-epoxy-9Z-octadecenoic acid } \\
\text { (12,13-EODE)/ } \\
\text { 9S-hydroxy-10E,12Z-octadecadienoic acid } \\
\text { (9S-HODE)/ } \\
\text { 13S-hydroxy-9Z,11E-octadecadienoic } \\
\text { acid(13S-HODE)/ } \\
\text { 9R,10S-epoxy-12Z-octadecenoic acid } \\
\text { (Coronaric acid/9,10-EODE) }\end{array}$ & $\mathrm{C}_{18} \mathrm{H}_{32} \mathrm{O}_{3}$ & $\begin{array}{l}13.89 / \\
14.09 / \\
14.86 / \\
15.13\end{array}$ & 296.2351 & 295.2279 & $\begin{array}{l}295.2278 / \\
295.2276 / \\
295.2277 / \\
295.2277\end{array}$ & $\begin{array}{c}\text { 195.1461; 277.2102; 295.1675; } \\
\text { 171.1026; 277.2171; 295.2276; } \\
\text { 195.1112; 277.1801 } \\
\text { 171.0891; 277.1552; }\end{array}$ \\
\hline $\begin{array}{c}\text { 17-Hydroxylinolenic acid/ } \\
\text { 9-oxo-10E,12Z-octadecadienoic acid } \\
\text { (9-KODE)/ } \\
\text { (9Z)-(13S)-12,13-Epoxyoctadeca-9,11- } \\
\text { dienoic acid } \\
\end{array}$ & $\mathrm{C}_{18} \mathrm{H}_{30} \mathrm{O}_{3}$ & $\begin{array}{l}13.47 / \\
14.66 / \\
14.87\end{array}$ & 294.2195 & 293.2122 & $\begin{array}{l}293.2123 / \\
293.2122 / \\
293.2122\end{array}$ & $\begin{array}{c}\text { 185.0921; 197.1032; 220.1291; } \\
\text { 221.1282; 293.8401; }\end{array}$ \\
\hline 9,12-Dioxododecanoic acid & $\mathrm{C}_{12} \mathrm{H}_{20} \mathrm{O}_{4}$ & 6.85 & 228.1362 & 227.1289 & 227.1284 & $227.1284,183.1284$ \\
\hline
\end{tabular}

Oleic acid is the main component of the cell membrane and cell nucleus and also facilitates the dissolution and absorption of fat-soluble vitamins, such as vitamin E [74]. Together with oleic acid, linolenic acid is involved in the prevention and treatment of cardiovascular and cerebrovascular diseases, thanks to cholesterol elimination [75].

Some saturated fatty acids derivatives like dioxo-hydroxy(6,9-dioxo-(11R,15S)-dihydroxy13E-prostenoic acid (6-keto PGE1), (R)-10-Hydroxystearate and (R)-2-Hydroxystearate were identified in chestnut methanolic extracts, which can serve as a nanocarrier for ocular delivery of bioactive substances [76]. Furthermore, hydroxy derivatives of octadecenoic and 
octadecadienoic acids, hydroperoxy derivatives of octadecadienoic and octadecatrienoic acids and epoxy derivatives of octadecenoic acid were identified, these compounds being used to reduce inflammation as a result of metabolic syndrome and cancer $[77,78]$.

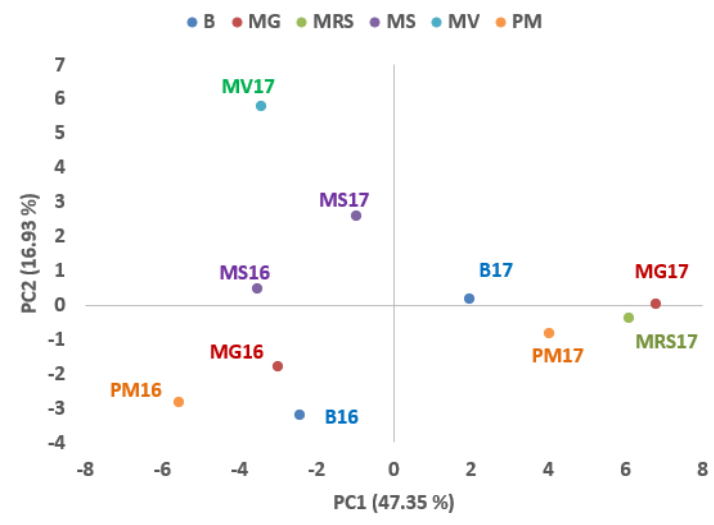

(a)

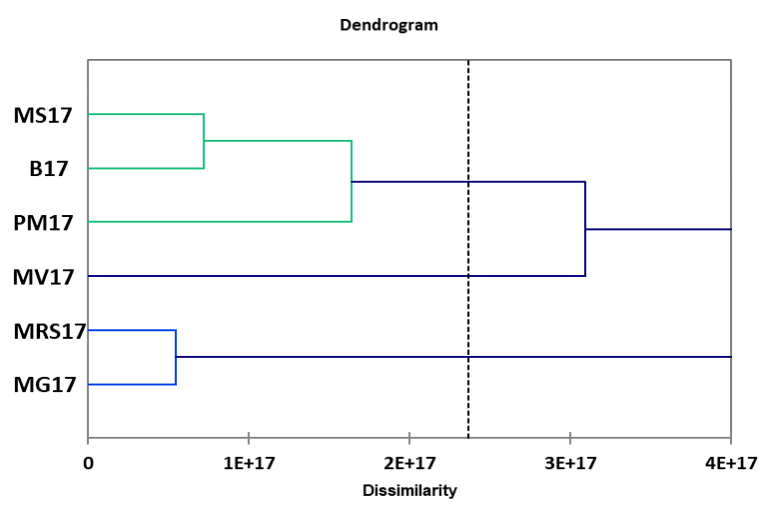

(b)

Figure 5. (a) PCA based on phytochemical and bioactive UHPLC/MS-MS fingerprints of the fruits of different chestnut cultivars harvested in 2016 and 2017 and (b) Dendrogram of the fruits of different chestnut cultivars harvested in 2017 ('Précoce Migoule'-PM, 'Bournette'-B, 'Marsol'—MS, 'Marissard'-MRS, 'Marigoule'-MG and 'Maraval'-MV).

Statistical analysis based on the qualitative data referring to saturated and unsaturated fatty acids fingerprints of the studied chestnut cultivars harvested in two years was performed in order to distinguish some possible groups. The results indicate that there are big differences in the fatty acid composition of chestnuts in different years, which leads to the identification of two distinct groups corresponding to the harvest years (Figure 6a), which suggest that variation in fatty acid composition depended firstly on the climatic conditions and subsequently on genotype. Lower precipitation and higher temperatures favored the accumulation of fatty acids [79].

HCA analysis indicates that, based on fatty acid and derivatives fingerprints, 'Précoce Migoule' and 'Bournette' form a distinct cluster, while 'Marsol', 'Marissard' and Marigoule are clustered together. 'Maraval' shows a distinct fatty acids profile, being clustered separately (Figure $7 \mathrm{~b}$ ).

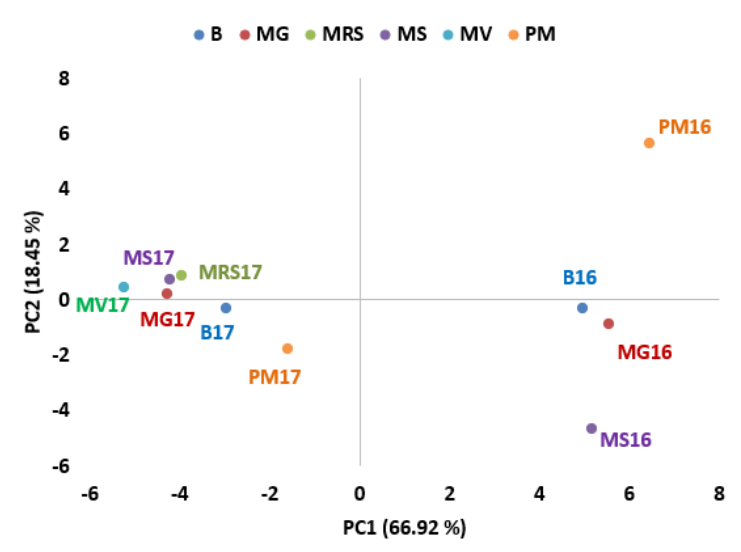

(a)

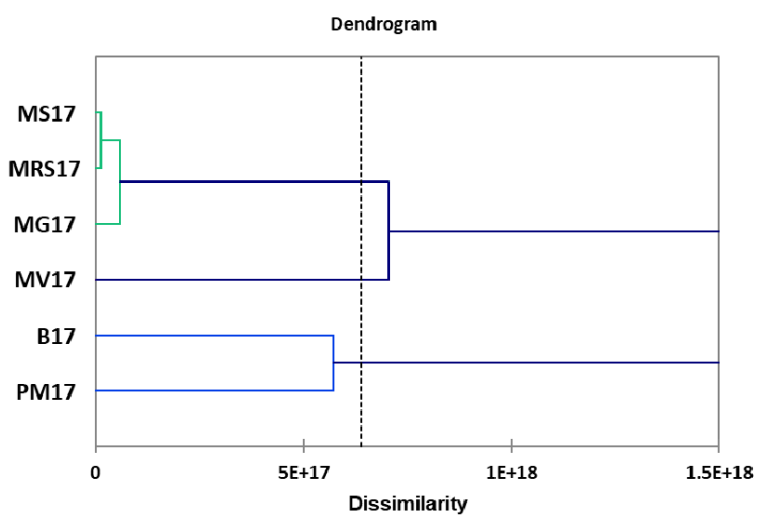

(b)

Figure 6. (a) PCA based on fatty acids and some derivatives UHPLC/MS-MS fingerprints of the fruits of different chestnut cultivars harvested in 2016 and 2017 and (b) Dendrogram of the fruits of different chestnut cultivars harvested in 2017 ('Précoce Migoule'—PM, 'Bournette'—B, 'Marsol'-MS, 'Marissard'-MRS, 'Marigoule'-MG and 'Maraval'-MV). 


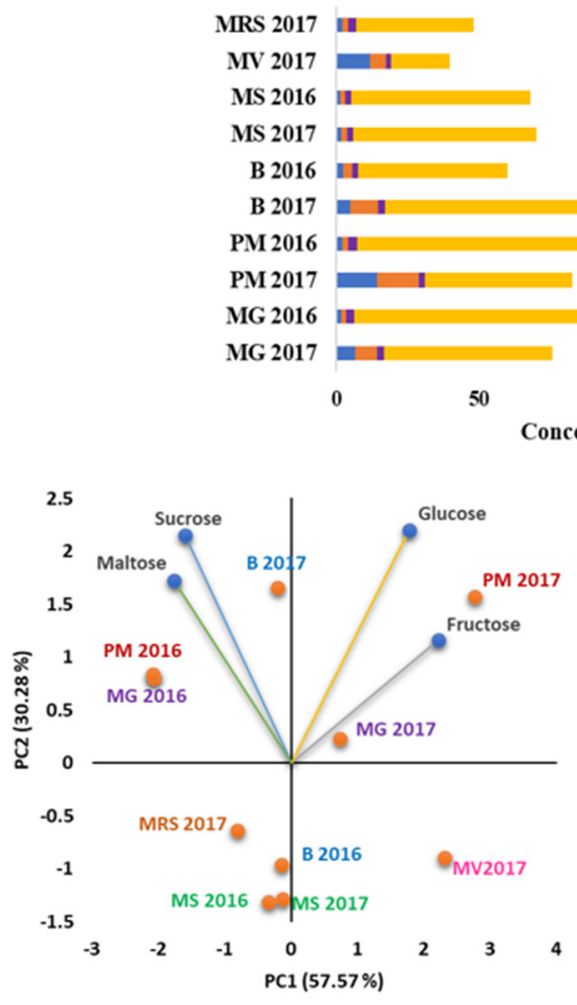

(b)

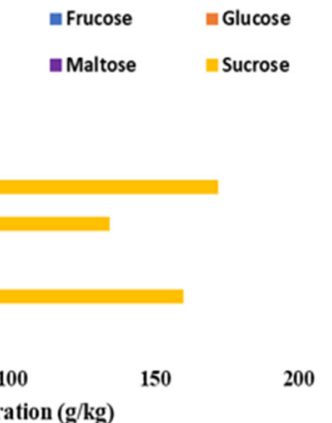

(a)

Figure 7. (a) Sugar profile of the analyzed chestnut cultivars harvested in 2016 and 2017; (b) Principal Component Analysis (PCA) of the fruits of different chestnut cultivars based on individual phenolic compounds ('Précoce Migoule'—PM, 'Bournette'—B, 'Marsol'—MS, 'Marissard'—MRS, 'Marigoule'MG and 'Maraval'-MV); (c) PCA analysis based on sugar composition of chestnut fruits harvested in some European countries.

\subsection{Sugars Profile of Different Chestnut Cultivars Harvested in Two Years}

Carbohydrates are relevant components in chestnuts, with sucrose being an important parameter in assessing the quality of the fruit. Together with sucrose, glucose and fructose are present in significant amounts in chestnuts, the profile of free sugars contributing to the identification of chestnut cultivars. Sugar profile can be influenced by several conditions, such as cultivars, genotypes, environmental factors (climatic conditions, soil characteristics) technical and cultural practices, and harvest time [10].

Large and significant differences $(p<0.0001)$ in sugar content values were detected among cultivars and harvest years (Table 5). The obtained data were expressed as mean values. The values in the same column followed by different lowercase letters differ significantly depending on the chestnut cultivar and harvest year, according to Duncan's multiple range test at $p \leq 0.0001$.

The highest quantity of sugars was observed for 'Bournette' in 2017, followed by 'Marigoule' and 'Précoce Migoule' in the 2016 harvest year (Figure 7a). Sucrose was the most abundant sugar in the analyzed chestnuts with values ranging from $20.34-154.94 \mathrm{~g} / \mathrm{kg} \mathrm{DW}$, the lower value corresponding to 'Maraval', while the highest value corresponds to 'Bournette' in 2017. The sucrose level of chestnut fruits cultivated in Romania is similar to those grown in Turkey (68.20-174.00 g/kg DW) [10], but lower compared with chestnut fruits cultivated in Italy (2.98 -245.09 g/ kg DW) [2] and Portugal (40.30-233.00 g/kg DW) [30] and higher compared with chestnut fruits cultivated in Tenerife (Spain) (31.10-99.40 g/kg DW) [29]. 
Table 5. Sugar content in different chestnut cultivars harvested in 2016 and 2017 (g/kg DW).

\begin{tabular}{cccccc}
\hline Chestnut Cultivar & Code & Fructose & Glucose & Sucrose & Maltose \\
\hline 'Bournette' (B) & B 2017 & $5.052 \mathrm{~d}$ & $9.536 \mathrm{~b}$ & $154.942 \mathrm{a}$ & $2.429 \mathrm{c}$ \\
'Précoce Migoule' & B 2016 & $2.645 \mathrm{e}$ & $2.99 \mathrm{e}$ & $51.967 \mathrm{~g}$ & $2.268 \mathrm{~d}$ \\
(PM) & PM 2017 & $14.346 \mathrm{a}$ & $14.456 \mathrm{a}$ & $51.461 \mathrm{~h}$ & $2.299 \mathrm{~d}$ \\
'Marigoule' (MG) & $2.026 \mathrm{f}$ & $2.099 \mathrm{~g}$ & $126.968 \mathrm{c}$ & $3.159 \mathrm{a}$ \\
& MG 2017 & $6.85 \mathrm{c}$ & $7.42 \mathrm{c}$ & $58.85 \mathrm{f}$ & $2.400 \mathrm{c}$ \\
'Marsol' (MS) & MG 2016 & $1.809 \mathrm{~g}$ & $1.795 \mathrm{~h}$ & $153.496 \mathrm{~b}$ & $2.885 \mathrm{~b}$ \\
'Marissard' (MRS) & MS 2017 & $1.900 \mathrm{~g}$ & $2.14 \mathrm{~g}$ & $63.915 \mathrm{~d}$ & $2.000 \mathrm{e}$ \\
'Maraval' (MV) & $1.550 \mathrm{~h}$ & $1.556 \mathrm{i}$ & $62.705 \mathrm{e}$ & $2.086 \mathrm{e}$ \\
\hline $\mathbf{R}^{2}$ & MV 2017 & $2.055 \mathrm{f}$ & $2.308 \mathrm{f}$ & $41.047 \mathrm{i}$ & $2.792 \mathrm{~b}$ \\
F & $11.894 \mathrm{~b}$ & $5.581 \mathrm{~d}$ & $20.343 \mathrm{j}$ & $1.766 \mathrm{f}$ \\
\hline Pr > F & & 0.9999 & 0.9999 & 1.0000 & 0.9941 \\
Significant & & 16979 & 11345 & 1073511 & 186 \\
& & $<0.0001$ & $<0.0001$ & $<0.0001$ & $<0.0001$ \\
\hline
\end{tabular}

Data are expressed as means. The lowercase letters in the column represent the different groups resulted from the interactions between the studied factors (cultivar and harvest year), according to Duncan's multiple range test at $p \leq 0.05$.

In general, fructose and glucose were quantified in equal amounts in the studied chestnut cultivars, with fructose ranging between 1.55-14.35 g/ $\mathrm{kg}$ DW and glucose ranging between 1.56-14.46 g/kg DW, the highest contents corresponding to 'Précoce Migoule' harvested in 2017 (Figure 7a). The higher fructose amount compared to the glucose one corresponds to 'Maraval', thus being considered as a functional food for consumers suffering from type 2 diabetes [80]. Our data were higher than those reported by other authors which found glucose and fructose concentrations between not detected and $3.1 \mathrm{~g} / \mathrm{kg}$ DW for both monosaccharides [81] or between $0.56-2.40 \mathrm{~g} / \mathrm{kg}$ DW for fructose and $0.49-1.90 \mathrm{~g} / \mathrm{kg}$ DW for glucose [29], but in the same range as Mert et al. who report fructose between $1.5-8.0 \mathrm{~g} / \mathrm{kg}$ DW and glucose between 4.0-11.3 g/ $\mathrm{kg}$ DW [10]. Maltose was quantified in low amounts, with values between 1.77 and $3.16 \mathrm{~g} / \mathrm{kg}$ DW. It can be concluded that the 2017 harvest year, in which there were higher temperatures and more abundant rainfall, was more favorable to accumulate sugars in 'Bournette', while the 2016 harvest year was more favorable for 'Marigoule' and 'Précoce Migoule' cultivars.

PCA analysis based on sugar profile (sucrose, fructose and glucose) of chestnut fruits grown in the main European chestnut producing countries (Italy, Portugal, Turkey, Spain) and the chestnut cultivated in Romania (Figure $7 \mathrm{~b}$ ), indicate a good correlation between the sugar content of chestnuts and climatic conditions, temperate continental corresponding in Romania and Turkey (around the Black Sea) characterized by an average temperature of $11.94{ }^{\circ} \mathrm{C}$ and $566.07 \mathrm{~mm}$ precipitation in Turkey and $10.51^{\circ} \mathrm{C}$ and $669.15 \mathrm{~mm}$ precipitation in Romania, compared with the temperate oceanic climate in Portugal (average temperature of $16.11{ }^{\circ} \mathrm{C}$ and $677.93 \mathrm{~mm}$ precipitation), the Mediterranean climate in Italy (average temperature of $13.35{ }^{\circ} \mathrm{C}$ and $791.32 \mathrm{~mm}$ precipitation) and the subtropical climate with some influences from Sahara in Tenerife (Spain) (average temperature of $14.47^{\circ} \mathrm{C}$ and 518.24 $\mathrm{mm}$ precipitation) (Table S3). The chestnuts from Portugal Italy, Spain and Turkey were grouped in distinct groups, while the chestnuts cultivated in Romania were overlapped on the others.

\subsection{Macro and Micronutrients Composition}

The content of macro-nutrients $(\mathrm{K}, \mathrm{Mg}, \mathrm{Ca}$ and $\mathrm{Na})$ and micronutrients $(\mathrm{Fe}, \mathrm{Cu})$ in fruits of different chestnut cultivars harvested in 2016 and 2017 was determined (Table 6). Furthermore, $\mathrm{Ni}$ was investigated as an essential plant micronutrient required for normal plant growth and development. Significant differences $(p<0.0001)$ in elemental content values were detected among cultivars and harvest years, suggesting that the cultivar and the climatic conditions influence the elemental composition of the chestnut fruits, the soil 
mineral composition being the same for all the studied cultivars. The data were expressed as mean values. The values in the same column followed by different lowercase letters differ significantly depending on the chestnut cultivar and harvest year, according to Duncan's multiple range test at $p \leq 0.0001$.

Table 6. Macro and micronutrients content in different chestnut fruits (Castanea sativa Mill) harvested in 2016 and 2017 (mg/100 g DW).

\begin{tabular}{lccccccc}
\hline & Ca & Mg & Na & K & Fe & Ni & Cu \\
\hline PM 2017 & $29.58 \mathrm{a}$ & $77.19 \mathrm{c}$ & $30.65 \mathrm{e}$ & $2166.46 \mathrm{~b}$ & $3.09 \mathrm{~b}$ & $0.90 \mathrm{~d}$ & $0.60 \mathrm{e}$ \\
PM 2016 & $16.87 \mathrm{i}$ & $104.81 \mathrm{a}$ & $26.39 \mathrm{~g}$ & $2652.11 \mathrm{a}$ & $2.51 \mathrm{c}$ & $1.47 \mathrm{a}$ & $0.86 \mathrm{~b}$ \\
B 2016 & $26.08 \mathrm{~b}$ & $102.88 \mathrm{~b}$ & $30.79 \mathrm{~d}$ & $860.02 \mathrm{f}$ & $2.15 \mathrm{e}$ & $1.03 \mathrm{c}$ & $0.64 \mathrm{~d}$ \\
MG 2016 & $22.92 \mathrm{c}$ & $54.68 \mathrm{i}$ & $22.65 \mathrm{~h}$ & $974.86 \mathrm{c}$ & $2.42 \mathrm{~d}$ & $1.38 \mathrm{~b}$ & $0.98 \mathrm{a}$ \\
MS 2016 & $21.90 \mathrm{~d}$ & $65.56 \mathrm{~h}$ & $26.57 \mathrm{f}$ & $867.16 \mathrm{e}$ & $2.10 \mathrm{~g}$ & $0.71 \mathrm{f}$ & $0.75 \mathrm{c}$ \\
B 2017 & $17.80 \mathrm{~g}$ & $77.15 \mathrm{~d}$ & $172.03 \mathrm{a}$ & $710.36 \mathrm{i}$ & $2.14 \mathrm{e}$ & $0.63 \mathrm{~g}$ & $0.47 \mathrm{~g}$ \\
MRS 2017 & $17.15 \mathrm{~h}$ & $66.42 \mathrm{~g}$ & $157.21 \mathrm{~b}$ & $884.42 \mathrm{~d}$ & $2.12 \mathrm{f}$ & $0.51 \mathrm{i}$ & $0.60 \mathrm{e}$ \\
MS 2017 & $14.01 \mathrm{j}$ & $48.62 \mathrm{j}$ & $33.17 \mathrm{c}$ & $403.56 \mathrm{j}$ & $3.43 \mathrm{a}$ & $0.21 \mathrm{j}$ & $0.54 \mathrm{f}$ \\
MV 2017 & $19.81 \mathrm{e}$ & $68.45 \mathrm{f}$ & $22.48 \mathrm{i}$ & $747.02 \mathrm{~h}$ & $2.09 \mathrm{~g}$ & $0.81 \mathrm{e}$ & $0.46 \mathrm{~h}$ \\
MG 2017 & $19.70 \mathrm{f}$ & $68.69 \mathrm{e}$ & $4.63 \mathrm{j}$ & $793.65 \mathrm{~g}$ & $1.89 \mathrm{~h}$ & $0.57 \mathrm{~h}$ & $0.31 \mathrm{i}$ \\
\hline R & 1.000 & 1.000 & 1.000 & 1.000 & 1.000 & 1.000 & 0.999 \\
F & 779,671 & $8,429,549$ & $121,574,044$ & $14,113,376,066$ & 14,976 & 14,441 & 2102 \\
Pr F & $<0.0001$ & $<0.0001$ & $<0.0001$ & $<0.0001$ & $<0.0001$ & $<0.0001$ & $<0.0001$ \\
Significant & Yes & Yes & Yes & Yes & Yes & Yes & Yes \\
\hline
\end{tabular}

Data are expressed as means the lowercase letters in the column represent the different groups resulting from the interactions between the studied factors (cultivar and harvest year), according to Duncan's multiple range test at $p \leq 0.05$.

Concerning the macronutrients, $\mathrm{K}$ was the most abundant, ranging between $403.56 \mathrm{mg} / 100 \mathrm{~g}$ DW and $2652.11 \mathrm{mg} / 100 \mathrm{~g}$ DW, followed by Na which ranged between $4.63 \mathrm{mg} / 100 \mathrm{~g}$ DW and $17.20 \mathrm{mg} / 100 \mathrm{~g}$ DW. Calcium contents ranged from $14.01 \mathrm{mg} / 100 \mathrm{~g}$ DW in 'Marsol' to $29.58 \mathrm{mg} / 100 \mathrm{~g}$ DW in 'Précoce Migoule', while Mg content varied between $48.62 \mathrm{mg} / 100 \mathrm{~g}$ in 'Marsol' and $102.88 \mathrm{mg} / 100 \mathrm{~g}$ DW in 'Précoce Migoule'. The obtained macronutrients values are higher than those reported in other studies, for the same cultivar, but cultivated in different geographical regions. For example, the macronutrient content of chestnut cultivar 'Marsol' is lower than that reported for 'Marsol' grown in Croatia (1383.90 mg/100 g for K, $39.20 \mathrm{mg} / 100 \mathrm{~g}$ for Na, $100.70 \mathrm{mg} / 100 \mathrm{~g}$ for Ca and $97.90 \mathrm{mg} / 100 \mathrm{~g}$ for Mg) [6] and the macronutrient content of the chestnut cultivar 'Marigoule' and 'Maraval' is lower or similar to that reported for the same cultivars in Turkey [27]. These differences could be explained by the poor content of the macronutrients in the clay-alluvial soil specific to the foothills outside the Carpathians (Vâlcea county) and the soil from Croatia and Turkey, which are less washed and less acidic due to the corresponding warm climate, and therefore, there is a great availability of these minerals from the soil to plant. With regard to micronutrients, chestnut fruits also contain significant amounts of Fe (1.84-3.43 mg/100 g DW) and $\mathrm{Cu}$ $(0.31-0.98 \mathrm{mg} / 100 \mathrm{~g} \mathrm{DW})$ which are similar to values found in other studies $[6,27]$, but lower than those obtained by several authors [23,82].

The Ni content in chestnut fruits ranged from 0.21 to $1.47 \mathrm{mg} / 100 \mathrm{~g} \mathrm{DW}$, proving that the chestnuts had a sufficient amount of Ni for normal growth and development, in general, the plants' Ni requirement was $0.5 \mathrm{mg}$ per kg of dry weight [83]. Furthermore, the Ni content in chestnut fruits does not exceed the maximum permissible values of $67.9 \mathrm{mg} / \mathrm{kg}$ in vegetables for human consumption [84].

The growing concern for a healthy diet rich in nutrients has become an important public health issue and this includes a balanced mineral intake. Potassium is a very significant body mineral, important to cellular and electrical functions, and is one of the main blood minerals called "electrolytes" [85]. Sodium along with potassium helps maintain the proper balance of body fluids, but it also helps to transmit nerve impulses and regulates muscle contraction and relaxation. Magnesium maintains the electrical potential 
of nerve tissues and cell membranes and has an important enzymatic role, being involved in the synthesis of proteins, RNA and DNA [11]. Calcium gives rigidity to the skeleton and is an important part of bones and teeth. Ca supplementation is essential for stimulating growth and preventing osteoporosis [86]. Micro-elements also play important roles in health. For example, iron is responsible for the synthesis and catabolism of some nutrients, being the essential components of enzymes involved in these processes. Additionally, iron is involved in transporting oxygen through red blood cell hemoglobin and for that, appropriate supplementation of Fe can effectively prevent anemia [87].

$\mathrm{K}$ was quantified in higher amounts in the 'Précoce Migoule' cultivar, while the lower content was observed for the 'Marsol' cultivar. Larger quantities of $\mathrm{Na}$ were identified in the 'Bournette' and 'Marissard' chestnut cultivars, while equal amounts of $\mathrm{Mg}$ and $\mathrm{Ca}$ were quantified in the studied chestnut cultivars (Figure 8a). Micronutrient profiles of the studied chestnut cultivars are similar, with small exceptions, such as Fe being quantified in high amounts in the 'Marsol' cultivar (Figure 8b). Among the studied chestnut cultivars, 'Précoce Migoule' showed the highest mineral content, while the lowest corresponded to 'Marsol'.

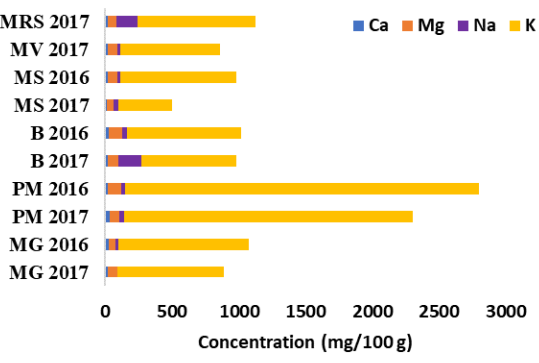

(a)

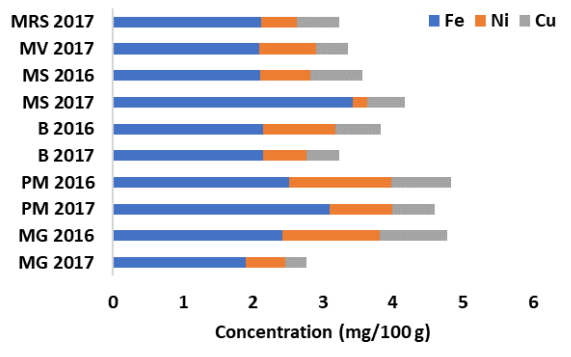

(b)

Figure 8. Mineral profile of the analyzed chestnut cultivars harvested in 2016 and 2017: (a) Ca, Mg, $\mathrm{Na}$ and $\mathrm{K} ;(\mathbf{b}) \mathrm{Fe}$, Ni and $\mathrm{Cu}$.

Using principal component analysis to classify cultivars according to the main nutrient components, we have found that the two main principal components accumulated more than $60.61 \%$ of the variance (Figure $9 a$ ). The first principal component (PC1) discriminated chestnut cultivars harvested in 2016 from those harvested in 2017. K, Ca, Mg, Cu and Ni nutrients were distributed towards the chestnut samples harvested in 2016, a year that was less warm compared with 2017 (Table 1), which favors the mobility and absorbance of individual nutrients from the soil, and consequently, the accumulation of minerals from the soil to the plant $[88,89]$. Na was distributed towards chestnut cultivars harvested in 2017, in which higher amounts of precipitation were recorded, which favors the mobility of Na from soil into the plant.

Because chestnut fruit mineral composition is not only associated with the genotype and climatic conditions but is also related to the mineral composition of the soil where the chestnut trees were grown, we try to discriminate the sweet chestnut fruits cultivated in Romania from those grown in the large chestnut-producing countries from Europa, such as Portugal, Turkey, Spain and Croatia, based on the available literature data $[3,6,23,27,83,90]$ (Figure 9b).

Clear discrimination can be observed for chestnuts harvested in Portugal and Croatia, while the chestnuts harvested in Turkey and Spain are overlapped. The chestnut samples harvested in Romania were partially overlapped on the others, indicating that a rigorous analysis, which takes into account all the variables (genotype, climatic conditions, soil characteristics) is required. 


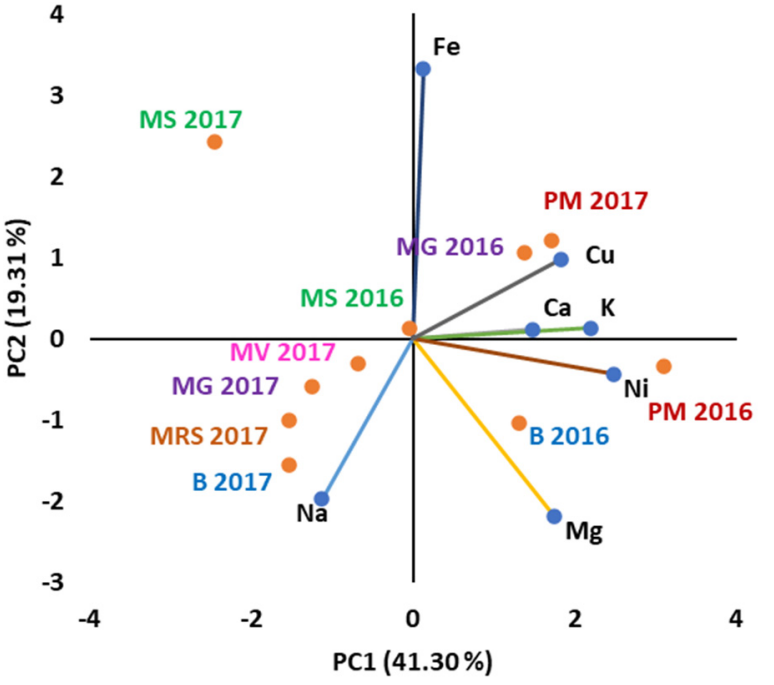

(a)

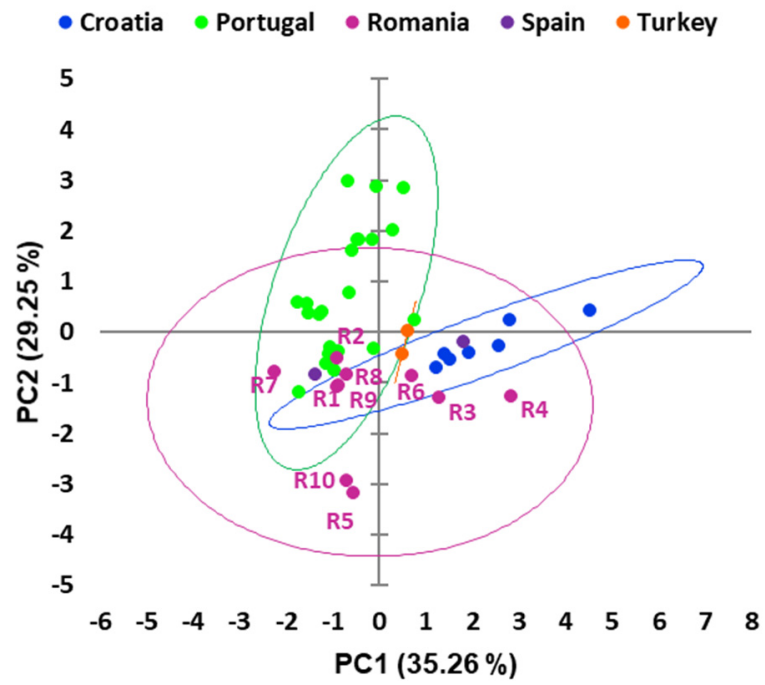

(b)

Figure 9. (a) PCA analysis based on mineral composition of fruits of different chestnut cultivars harvested in Romania in 2016 and 2017 ('Précoce Migoule'-PM, 'Bournette'—B, 'Marsol'-MS, 'Marissard'-MRS, 'Marigoule'-MG and 'Maraval'-MV) and (b) PCA analysis based on mineral composition of chestnut fruits harvested in some European countries.

\section{Conclusions}

This study highlights, for the first time, a comprehensive bioactive characterization of 'Marsol', 'Maraval', 'Bournette', 'Précoce Migoule' and 'Marissard' sweet chestnut cultivars grown at Fruit Growing Research-Extension Station (SCDP) Vâlcea, in Northern Oltenia, Romania in order to provide valuable information for selection of the chestnut cultivar with high quality bioactive characteristics that can be cultivated for the development of different value-added food products with multiple benefits on human health.

Based on total polyphenolic content, total flavonoids, antioxidant activity and individual phenolic compounds profile, no significant differences were observed between the studied cultivars, a higher bioactive potential corresponding to 'Marissard', was followed by 'Précoce Migoule', 'Marigoule' and 'Bournette'. Based on gallic and cinnamic acids and rutin some differences can be observed between the studied cultivars variables, with 'Bournette' showing higher gallic acid content and lower cinnamic acid, while 'Marissard' showed the highest cinnamic acid and rutin amounts. Discriminant analysis indicates a clear discrimination between the chestnut fruits harvested in different years, indicating that climatic conditions play o significant contribution to the synthesis of chestnut fruit's bioactive compounds, warm temperature and drought favoring their accumulation and thus, obtaining a crop rich in bioactive compounds, such as gallic, ellagic, cinnamic, chlorogenic and caffeic acids, (+)-catechin and (-)-epicatechin.

Screening HRMS analysis coupled with data processing analysis using Compound Discoverer software based on an untargeted metabolomics working template allows the identification of other bioactive compounds in chestnut hydro-methanolic extracts, such as phytochemical compounds (flavanols, isoflavones, calchones, anthocyanidin derivatives, terpenoids and sesquiterpenoids, vitamins, gibberellin plant hormones, metabolites), fatty acids (saturated and unsaturated fatty acids and derivatives), amino acids and organic acids which are likely responsible for their antioxidant and anti-inflammatory activities.

Statistical analysis based on the qualitative data referring to phytochemical fingerprints and saturated and unsaturated fatty acids fingerprints indicates a clear discrimination of chestnut fruits harvested in different years, indicating that chestnut's phytochemical and fatty acid fingerprints depended firstly on the climatic conditions and subsequently on genotype. Based on HRMS phytochemical fingerprints, 'Marigoule' and 'Marissard' were 
grouped separated from the other cultivars, while based on fatty acid and derivatives fingerprints, 'Précoce Migoule' and 'Bournette' form a distinct cluster from the other cultivars. Quantitative data would be very useful for the identification of chestnut cultivars with high phytochemical and fatty acid composition.

Large and significant differences $(p<0.0001)$ in sugar and mineral composition were detected among cultivars and harvest years. The cultivar and climatic conditions influence the sugar composition, with the highest quantity of sugars being observed for the 'Bournette' cultivar in 2017, which was warmer and rainier compared to 2016, while the 2016 harvest year was more favorable for the accumulation of sugars in 'Marigoule' and 'Précoce Migoule' cultivars. The cultivar and the climatic conditions influence the elemental composition of the chestnut fruits, with the soil mineral composition being the same for all the studied cultivars. The 'Précoce Migoule' cultivar shows higher macro and micronutrient contents, with $\mathrm{K}$ being the most abundant nutrient. Larger quantities of $\mathrm{Na}$ were identified in 'Bournette' and 'Marissard', while equal amounts of Mg and Ca were quantified in the studied chestnut cultivars.

PCA analysis based on sugar profile (sucrose, fructose and glucose) and mineral composition of chestnut fruits grown in Romania and those cultivated in the main European chestnut producing countries (Italy, Portugal, Turkey, Spain) indicates a good correlation between the sugar and mineral contents of chestnuts and climatic conditions corresponding to the different geographical areas. It can, thus, be concluded that climatic and soil characteristics corresponding to Northern Oltenia, Romania favors the accumulation of sugars and minerals, and thus, it is possible to obtain crops with nutritional characteristics similar to those obtained in the specific area of culture.

Supplementary Materials: The following supporting information can be downloaded at: https: / /www.mdpi.com/article/10.3390/separations9030066/s1, Figure S1. Correlation between: (a) Total Polyphenolics with antioxidant activity and (b) Total Flavonoids with antioxidant activity; Figure S2. Variation of the antioxidant activity (AA), Total polyphenolics (TP) and Total Flavonoids (TF) in chestnut fruits of different sweet cultivars; Figure S3. Variation of individual phenolic compounds (gallic acid-GA, cinnamic acid-CA and rutin- $\mathrm{R}$ ) in chestnut fruits of different sweet cultivars harvested in 2016 and 2017; Figure S4. Untargeted Metabolomics workflow: Find and identify the differences between samples; Figure S5. TIC and the extracted chromatograms of the main phytochemical compounds identified in chestnut methanolic extract; Figure S6. TIC and the extracted chromatograms of the main saturated (a) and unsaturated (b) fatty acids identified in chestnut methanolic extract; Figure S7. TIC and the extracted chromatograms of the main amino acids identified in chestnut methanolic extract; Figure S8. TIC and the extracted chromatograms of the main gibberellin plant hormones identified in chestnut methanolic extract; Table S1. Sums of Growing Degree Hours and Growing Degree Days for the sweet chestnut cultivars; Table S2. Quality performance data for the phenolic acids and flavonoids profiling by UHPLC-MS/MS in negative ionization mode; Table S3. Climatic conditions (temperature and precipitation) in the main European chestnut producing countries and Romania during 2017, 2016 and 2017 harvest year according to https:/ / climateknowledgeportal.worldbank.org/ (accessed on 7 February 2022).

Author Contributions: Conceptualization, E.-I.G. and C.T.C.; methodology, E.-I.G. and C.T.C.; software, E.-I.G. and C.T.C.; validation, E.-I.G. and C.T.C.; formal analysis, E.-I.G., C.T.C. and C.S.; investigation, E.-I.G., C.T.C. and C.S.; resources, M.B.; data curation, E.-I.G.; writing-original draft preparation, E.-I.G., C.T.C., M.B.; writing—review and editing, E.-I.G., O.T., M.B.; visualization, O.T., M.B.; supervision, O.T., M.B. All authors have read and agreed to the published version of the manuscript.

Funding: This work was carried out through the Core Program, carried out with the support of Ministry of Research, Innovation and Digitization, project no. PN 19110302 "Research on the variation trends specific to stable isotopes in different tree species: deepening the fractionation mechanisms and the chemical processes interconnected on the soil-water-plant chain".

Data Availability Statement: Not applicable.

Conflicts of Interest: The authors declare no conflict of interest. 


\section{References}

1. Míguez-Soto, B.; Fernández-Cruz, J.; Fernández-López, J. Mediterranean and Northern Iberian gene pools of wild Castanea sativa Mill. are two differentiated ecotypes originated under natural divergent selection. PLoS ONE 2019, 14, e0211315. [CrossRef] [PubMed]

2. Beccaro, G.L.; Donno, D.; Lione, G.G.; De Biaggi, M.; Gamba, G.; Rapalino, S.; Riondato, I.; Gonthier, P.; Mellano, M.G. Castanea spp. Agrobiodiversity Conservation: Genotype Influence on Chemical and Sensorial Traits of Cultivars Grown on the Same Clonal Rootstock. Foods 2020, 9, 1062. [CrossRef] [PubMed]

3. Choupina, A.B. Nutritional and health potential of European chestnut. Rev. Ciências Agrárias 2019, 42, 801-807. [CrossRef]

4. Akbulut, M.; Bozhuyuk, M.R.; Ercisli, S.; Skender, A.; Sorkheh, K. Chemical Composition of Seed Propagated Chestnut Genotypes from Northeastern Turkey. Not. Bot. Horti Agrobot. 2017, 45, 425-430. [CrossRef]

5. Otles, S.; Selek, I. Phenolic compounds and antioxidant activities of chestnut (Castanea sativa Mill.) fruits. Qual. Assur. Saf. Crop. Foods 2012, 4, 199-205. [CrossRef]

6. Poljak, I.; Vahčić, N.; Vidaković, A.; Tumpa, K.; Žarković, I.; Idžojtić, M. Traditional Sweet Chestnut and Hybrid Varieties: Chemical Composition, Morphometric and Qualitative Nut Characteristics. Agronomy 2021, 11, 516. [CrossRef]

7. Gonçalves, B.; Borges, O.; Costa, H.S.; Bennett, R.; Santos, M.; Silva, A.P. Metabolite composition of chestnut (Castanea sativa Mill.) upon cooking: Proximate analysis, fibre, organic acids and phenolics. Food Chem. 2010, 122, 154-160. [CrossRef]

8. El Khoury, D.; Balfour-Ducharme, S.; Joye, I.J. A Review on the Gluten-Free Diet: Technological and Nutritional Challenges. Nutrients 2018, 10, 1410. [CrossRef]

9. $\quad$ Rodrigues, P.; Ferreira, T.; Nascimento-Gonçalves, E.; Seixas, F.; da Costa, R.M.G.; Martins, T.; Neuparth, M.J.; Pires, M.J.; Lanzarin, G.; Félix, L.; et al. Dietary Supplementation with Chestnut (Castanea sativa) Reduces Abdominal Adiposity in FVB/n Mice: A Preliminary Study. Biomedicines 2020, 8, 75. [CrossRef]

10. Mert, C.; Ertürk, Ü. Chemical Compositions and Sugar Profiles of Consumed Chestnut Cultivars in the Marmara Region, Turkey. Not. Bot. Horti Agrobot. 2017, 45, 203-207. [CrossRef]

11. Da, L.R.; Silva, B.M. Natural Bioactive Compounds from Fruits and Vegetables as Health Promoters; Bentham Science Publishers: Sharjah, United Arab Emirates, 2016.

12. Vella, F.M.; Laratta, B.; La Cara, F.; Morana, A. Recovery of bioactive molecules from chestnut (Castanea sativa Mill.) by-products through extraction by different solvents. Nat. Prod. Res. 2017, 32, 1022-1032. [CrossRef] [PubMed]

13. Brochard, M.; Correia, P.; Barroca, M.J.; Guiné, R.P.F. Development of a New Pasta Product by the Incorporation of Chestnut Flour and Bee Pollen. Appl. Sci. 2021, 11, 6617. [CrossRef]

14. Pinto, D.; Rodrigues, F.; Braga, N.; Santos, J.; Pimentel, F.B.; Palmeira-De-Oliveira, A.; Oliveira, M.B.P.P. The Castanea sativa bur as a new potential ingredient for nutraceutical and cosmetic outcomes: Preliminary studies. Food Funct. 2017, 8, 201-208. [CrossRef] [PubMed]

15. Silva, V.; Falco, V.; Dias, M.I.; Barros, L.; Silva, A.; Capita, R.; Alonso-Calleja, C.; Amaral, J.S.; Igrejas, G.; Ferreira, I.C.F.R.; et al. Evaluation of the Phenolic Profile of Castanea sativa Mill. By-Products and Their Antioxidant and Antimicrobial Activity against Multiresistant Bacteria. Antioxidants 2020, 9, 87. [CrossRef] [PubMed]

16. You, T.T.; Zhou, S.K.; Wen, J.L.; Ma, C.; Xu, F. Chemical Composition, Properties, and Antimicrobial Activity of the Water-Soluble Pigments from Castanea mollissima Shells. J. Agric. Food Chem. 2014, 62, 1936-1944. [CrossRef] [PubMed]

17. Morales, A.; Gullón, B.; Dávila, I.; Eibes, G.; Labidi, J.; Gullón, P. Optimization of alkaline pretreatment for the co-production of biopolymer lignin and bioethanol from chestnut shells following a biorefinery approach. Ind. Crops Prod. 2018, 124, 582-592. [CrossRef]

18. Pinto, D.; Cádiz-Gurrea, M.d.1.L.; Vallverdú-Queralt, A.; Delerue-Matos, C.; Rodrigues, F. Castanea sativa shells: A review on phytochemical composition, bioactivity and waste management approaches for industrial valorization. Food Res. Int. 2021, 144, 110364. [CrossRef]

19. Corona, P.; Frangipane, M.T.; Moscetti, R.; Feudo, G.L.; Castellotti, T.; Massantini, R. Chestnut Cultivar Identification through the Data Fusion of Sensory Quality and FT-NIR Spectral Data. Foods 2021, 10, 2575. [CrossRef]

20. Barreira, J.C.M.; Casal, S.; Ferreira, I.C.F.R.; Oliveira, M.B.P.P.; Pereira, J.A. Nutritional, Fatty Acid and Triacylglycerol Profiles of Castanea sativa Mill. Cultivars: A Compositional and Chemometric Approach. J. Agric. Food Chem. 2009, 57, 2836-2842. [CrossRef]

21. Barreira, J.C.M.; Casal, S.; Ferreira, I.C.F.R.; Peres, A.M.; Pereira, J.A.; Oliveira, M.B.P.P. Chemical characterization of chestnut cultivars from three consecutive years: Chemometrics and contribution for authentication. Food Chem. Toxicol. 2012, 50, $2311-2317$. [CrossRef]

22. Peña-Méndez, E.M.; Hernández-Suárez, M.; Díaz-Romero, C.; Rodríguez-Rodríguez, E. Characterization of various chestnut cultivars by means of chemometrics approach. Food Chem. 2008, 107, 537-544. [CrossRef]

23. De Vasconcelos, M.C.B.M.; Bennett, R.N.; Rosa, E.A.S.; Ferreira-Cardoso, J.V. Composition of European chestnut (Castanea sativa Mill.) and association with health effects: Fresh and processed products. J. Sci. Food Agric. 2010, 90, 1578-1589. [CrossRef] [PubMed]

24. Mota, M.; Pinto, T.; Vilela, A.; Marques, T.; Borges, A.; Caço, J.; Ferreira-Cardoso, J.; Raimundo, F.; Gomes-Laranjo, J. Irrigation positively affects the chestnut's quality: The chemical composition, fruit size and sensory attributes. Sci. Hortic. 2018, 238, 177-186. [CrossRef]

25. Furones-Pérez, P.; Fernández-López, J. Morphological and phenological description of 38 sweet chestnut cultivars (Castanea sativa Miller) in a contemporary collection. Spanish J. Agric. Res. 2009, 7, 829-843. [CrossRef] 
26. De Vasconcelos, M.D.C.B.M.; Bennett, R.N.; Rosa, E.A.S.; Cardoso, J.V.F. Primary and secondary metabolite composition of kernels from three cultivars of Portuguese chestnut (Castanea sativa Mill.) at different stages of industrial transformation. J. Agric. Food Chem. 2007, 55, 3508-3516. [CrossRef]

27. Ertürk, Ü.; Mert, C.; Soylu, A. Chemical composition of fruits of some important chestnut cultivars. Braz. Arch. Biol. Technol. 2006, 49, 183-188. [CrossRef]

28. Delgado, T.; Ramalhosa, E.; Pereira, J.A.; Casal, S. Organic acid profile of chestnut (Castanea sativa Mill.) as affected by hot air convective drying. Int. J. Food Prop. 2018, 21, 557-565. [CrossRef]

29. Suárez, M.H.; Galdón, B.R.; Mesa, D.R.; Romero, C.D.; Rodríguez, E.R. Sugars, Organic Acids and Total Phenols in Varieties of Chestnut Fruits from Tenerife (Spain). Food Nutr. Sci. 2012, 3, 705-715. [CrossRef]

30. Barreira, J.C.M.; Pereira, J.A.; Oliveira, M.B.P.P.; Ferreira, I.C.F.R. Sugars Profiles of Different Chestnut (Castanea sativa Mill.) and Almond (Prunus dulcis) Cultivars by HPLC-RI. Plant Foods Hum. Nutr. 2010, 65, 38-43. [CrossRef]

31. Leichtweis, M.G.; Oliveira, M.B.P.P.; Ferreira, I.C.F.R.; Pereira, C.; Barros, L. Sustainable Recovery of Preservative and Bioactive Compounds from Food Industry Bioresidues. Antioxidants 2021, 10, 1827. [CrossRef]

32. Chira, D.; Bolea, V.; Botu, M.; Giorgi, N.; Juveloiu, E. Sweet chestnut (Castanea sativa Mill.) forest in Romania: Distribution, current state, management and research activities. Revista Silvicultură Cinegetică 2013, 33, 15-20.

33. Cosmulescu, S.; Trandafir, I.; Nour, V.; Botu, M. Physical and compositional characteristics of chestnut fruits. Rom. J. Hortic. 2020, 1, 51-58. [CrossRef]

34. Ciucure, C.T.; Geană, E.I. Phenolic compounds profile and biochemical properties of honeys in relationship to the honey floral sources. Phytochem. Anal. 2019, 30, 481-492. [CrossRef] [PubMed]

35. Geană, E.-I.; Ciucure, C.T.; Ionete, R.E.; Ciocârlan, A.; Aricu, A.; Ficai, A.; Andronescu, E. Profiling of Phenolic Compounds and Triterpene Acids of Twelve Apple (Malus domestica Borkh.) Cultivars. Foods 2021, 10, 267. [CrossRef] [PubMed]

36. Geană, E.-I.; Ciucure, C.T.; Costinel, D.; Ionete, R.E. Evaluation of honey in terms of quality and authenticity based on the general physicochemical pattern, major sugar composition and $\delta^{13} \mathrm{C}$ signature. Food Control 2020, 109, 106919. [CrossRef]

37. Chiriac, E.R.; Chiţescu, C.L.; Sandru, C.; Geană, E.-I.; Lupoae, M.; Dobre, M.; Borda, D.; Gird, C.E.; Boscencu, R. Comparative study of the bioactive properties and elemental composition of red clover (Trifolium pratense) and alfalfa (Medicago sativa) sprouts during germination. Appl. Sci. 2020, 10, 7249. [CrossRef]

38. Daramola, B. Preliminary investigation on antioxidant interactions between bioactive components of Solanum anguivi and Capsicum annuum. J. Food Sci. Technol. 2018, 55, 3827-3832. [CrossRef]

39. Šamec, D.; Karalija, E.; Šola, I.; Vujčić Bok, V.; Salopek-Sondi, B. The Role of Polyphenols in Abiotic Stress Response: The Influence of Molecular Structure. Plants 2021, 10, 118. [CrossRef]

40. Zavalloni, C.; Andresen, J.A.; Flore, J.A. Phenological Models of Flower Bud Stages and Fruit Growth of 'Montmorency' Sour Cherry Based on Growing Degree-day Accumulation. J. Am. Soc. Hortic. Sci. 2006, 131, 601-607. [CrossRef]

41. Dinis, L.T.; Peixoto, F.; Pinto, T.; Costa, R.; Bennett, R.N.; Gomes-Laranjo, J. Study of morphological and phenological diversity in chestnut trees ('Judia' variety) as a function of temperature sum. Environ. Exp. Bot. 2011, 70, 110-120. [CrossRef]

42. Santos, J.A.; Costa, R.; Fraga, H. Climate change impacts on thermal growing conditions of main fruit species in Portugal. Clim. Change 2017, 140, 273-286. [CrossRef]

43. Soifoini, T.; Donno, D.; Jeannoda, V.; Rakoto, D.D.; Msahazi, A.; Farhat, S.M.M.; Oulam, M.Z.; Beccaro, G.L. Phytochemical composition, antibacterial activity, and antioxidant properties of the artocarpus altilis fruits to promote their consumption in the comoros islands as potential health-promoting food or a source of bioactive molecules for the food industry. Foods 2021, 10, 2136. [CrossRef] [PubMed]

44. Ruwizhi, N.; Aderibigbe, B.A. Cinnamic Acid Derivatives and Their Biological Efficacy. Int. J. Mol. Sci. 2020, 21, 5712. [CrossRef] [PubMed]

45. Camilla Bergonzi, M.; Heard, C.M.; Lupaescu, A.-V.; Iavorschi, M.; Covasa, M. The Use of Bioactive Compounds in Hyperglycemia and Amyloid Fibrils-Induced Toxicity in Type 2 Diabetes and Alzheimer's Disease. Pharmaceutics 2022, 14, 235. [CrossRef]

46. Ganeshpurkar, A.; Saluja, A.K. The Pharmacological Potential of Rutin. Saudi Pharm. J. 2017, 25, 149-164. [CrossRef]

47. Kahkeshani, N.; Farzaei, F.; Fotouhi, M.; Alavi, S.S.; Bahramsoltani, R.; Naseri, R.; Momtaz, S.; Abbasabadi, Z.; Rahimi, R.; Farzaei, M.H.; et al. Pharmacological effects of gallic acid in health and disease: A mechanistic review. Iran. J. Basic Med. Sci. 2019, 22, 225-237. [CrossRef]

48. Esposito, T.; Celano, R.; Pane, C.; Piccinelli, A.L.; Sansone, F.; Picerno, P.; Zaccardelli, M.; Aquino, R.P.; Mencherini, T. Chestnut (Castanea sativa Miller.) Burs Extracts and Functional Compounds: UHPLC-UV-HRMS Profiling, Antioxidant Activity, and Inhibitory Effects on Phytopathogenic Fungi. Molecules 2019, 24, 302. [CrossRef]

49. Hohrenk, L.L.; Itzel, F.; Baetz, N.; Tuerk, J.; Vosough, M.; Schmidt, T.C. Comparison of Software Tools for Liquid ChromatographyHigh-Resolution Mass Spectrometry Data Processing in Nontarget Screening of Environmental Samples. Anal. Chem. 2020, 92, 1898-1907. [CrossRef]

50. Ruiz-Cruz, S.; Chaparro-Hernández, S.; Hernández-Ruiz, K.L.; Cira-Chávez, L.A.; Estrada-Alvarado, M.I.; Gassos Ortega, L.E.; De, J.; Ornelas-Paz, J.; Lopez Mata, M.A. Flavonoids: Important Biocompounds in Food. In Flavonoids From Biosynthesis to Human Health; Intechopen: London, UK, 2017. [CrossRef]

51. Dias, M.C.; Pinto, D.C.G.A.; Silva, A.M.S. Plant Flavonoids: Chemical Characteristics and Biological Activity. Molecules 2021, $26,5377$. [CrossRef] 
52. Jucá, M.M.; Filho, F.M.S.C.; de Almeida, J.C.; Mesquita, D.d.S.; Barriga, J.R.d.M.; Dias, K.C.F.; Barbosa, T.M.; Vasconcelos, L.C.; Leal, L.K.A.M.; Ribeiro, J.E.; et al. Flavonoids: Biological activities and therapeutic potential. Nat. Prod. Res. 2018, 34, 692-705. [CrossRef]

53. Fraga, C.G.; Croft, K.D.; Kennedy, D.O.; Tomás-Barberán, F.A. The effects of polyphenols and other bioactives on human health. Food Funct. 2019, 10, 514-528. [CrossRef] [PubMed]

54. Ghasemzadeh, A.; Jaafar, H.Z.E.; Rahmat, A.; Feliciano, A.S.; Santos-Buelga, C. Variation of the Phytochemical Constituents and Antioxidant Activities of Zingiber officinale var. rubrum Theilade Associated with Different Drying Methods and Polyphenol Oxidase Activity. Molecules 2016, 21, 780. [CrossRef] [PubMed]

55. Vargas-Diez, E.; Hofmann, M.A.; Bravo, B.; Malgazhdarova, G.; Katkhanova, O.A.; Yutskovskaya, Y. Azelaic Acid in the Treatment of Acne in Adult Females: Case Reports. Skin Pharmacol. Physiol. 2014, 27, 18-25. [CrossRef]

56. Zadernowski, R.; Czaplicki, S.; Naczk, M. Phenolic acid profiles of mangosteen fruits (Garcinia mangostana). Food Chem. 2009, 112, 685-689. [CrossRef]

57. Méndez-Cuesta, C.A.; Laura, A.; Campos, E.; Sánchez, D.S.; González, C.P.; Gutiérrez, S.P. Cytotoxic and Antitumoral Activities of Compounds Isolated from Cucurbitaceae Plants. In Pharmacognosy Medicinal Plants; IntechOpen: London, UK, 2018. [CrossRef]

58. Gudoityte, E.; Arandarcikaite, O.; Mazeikiene, I.; Bendokas, V.; Liobikas, J. Ursolic and Oleanolic Acids: Plant Metabolites with Neuroprotective Potential. Int. J. Mol. Sci. 2021, 22, 4599. [CrossRef] [PubMed]

59. Zocchi, E.; Hontecillas, R.; Leber, A.; Einerhand, A.; Carbo, A.; Bruzzone, S.; Tubau-Juni, N.; Philipson, N.; Zoccoli-Rodriguez, V.; Sturla, L.; et al. Abscisic Acid: A Novel Nutraceutical for Glycemic Control. Front. Nutr. 2017, 4, 24. [CrossRef]

60. Gonçalves, M.J.; Cruz, M.T.; Tavares, A.C.; Cavaleiro, C.; Lopes, M.C.; Canhoto, J.; Salgueiro, L. Composition and biological activity of the essential oil from Thapsia minor, a new source of geranyl acetate. Ind. Crop. Prod. 2012, 35, 166-171. [CrossRef]

61. Binenbaum, J.; Weinstain, R.; Shani, E. Gibberellin Localization and Transport in Plants. Trends Plant Sci. 2018, $23,410-421$. [CrossRef]

62. Zhang, C.; Tanabe, K.; Tani, H.; Nakajima, H.; Mori, M.; Sakuno, E. Biologically Active Gibberellins and Abscisic Acid in Fruit of Two Late-maturing Japanese Pear Cultivars with Contrasting Fruit Size. J. Am. Soc. Hortic. Sci. 2007, 132, 452-458. [CrossRef]

63. Toner, P.; Nelson, D.; Rao, J.R.; Ennis, M.; Moore, J.E.; Schock, B. Antimicrobial properties of phytohormone (gibberellins) against phytopathogens and clinical pathogens. Access Microbiol. 2021, 3, 278. [CrossRef]

64. Zhou, P.; Zhang, P.; Guo, M.; Li, M.; Wang, L.; Adeel, M.; Shakoor, N.; Rui, Y. Effects of age on mineral elements, amino acids and fatty acids in Chinese chestnut fruits. Eur. Food Res. Technol. 2021, 247, 2079-2086. [CrossRef]

65. Akram, M.; Daniyal, M.; Ali, A.; Zainab, R.; Muhammad, S.; Shah, A.; Munir, N.; Tahir, I.M. Role of Phenylalanine and Its Metabolites in Health and Neurological Disorders. In Synucleins-Biochemisty and Role in Diseases; IntechOpen: London, UK, 2020. [CrossRef]

66. Höglund, E.; Øverli, Ø.; Winberg, S. Tryptophan metabolic pathways and brain serotonergic activity: A comparative review. Front. Endocrinol. 2019, 10, 158. [CrossRef] [PubMed]

67. James, S.P.; Bondugji, D. Gamma-Aminobutyric Acid (GABA) and the Endocannabinoids: Understanding the Risks and Opportunities. In Natural Drugs from Plants; IntechOpen: London, UK, 2021. [CrossRef]

68. Fernstrom, J.D.; Fernstrom, M.H. Tyrosine, Phenylalanine, and Catecholamine Synthesis and Function in the Brain. J. Nutr. 2007, 137, 1539S-1547S. [CrossRef]

69. Abdel-Salam, O.M.E.; Youness, E.R.; Mohammed, N.A.; Morsy, S.M.Y.; Omara, E.A.; Sleem, A.A. Citric Acid Effects on Brain and Liver Oxidative Stress in Lipopolysaccharide-Treated Mice. J. Med. Food 2014, 17, 588. [CrossRef]

70. Qiang, F. Effect of Malate-oligosaccharide Solution on Antioxidant Capacity of Endurance Athletes. Open Biomed. Eng. J. 2015, 9, 326. [CrossRef] [PubMed]

71. Fernández, S.; Ferrero, M. Strategies for the Synthesis of 19-nor-Vitamin D Analogs. Pharmacology 2020, 13, 159. [CrossRef]

72. Devaki, S.J.; Raveendran, R.L. Vitamin C: Sources, Functions, Sensing and Analysis. In Vitamin C; InTech: Rijeka, Croatia, 2017. [CrossRef]

73. Guo, S.; Duan, J.A.; Zhang, Y.; Qian, D.; Tang, Y.; Zhu, Z.; Wang, H.; McPhee, D.J. Contents Changes of Triterpenic Acids, Nucleosides, Nucleobases, and Saccharides in Jujube (Ziziphus jujuba) Fruit During the Drying and Steaming Process. Molecules 2015, 20, 22329-22340. [CrossRef] [PubMed]

74. Reboul, E. Vitamin E intestinal absorption: Regulation of membrane transport across the enterocyte. IUBMB Life 2019, 71, 416-423. [CrossRef]

75. Visioli, F.; Poli, A. Fatty Acids and Cardiovascular Risk. Evidence, Lack of Evidence, and Diligence. Nutrients 2020, $12,3782$. [CrossRef]

76. Hou, Y.; Zhang, F.; Lan, J.; Sun, F.; Li, J.; Li, M.; Song, K.; Wu, X. Ultra-small micelles based on polyoxyl 15 hydroxystearate for ocular delivery of myricetin: Optimization, in vitro, and in vivo evaluation. Drug Deliv. 2019, 26, 158-167. [CrossRef]

77. Vangaveti, V.N.; Jansen, H.; Kennedy, R.L.; Malabu, U.H. Hydroxyoctadecadienoic acids: Oxidised derivatives of linoleic acid and their role in inflammation associated with metabolic syndrome and cancer. Eur. J. Pharmacol. 2016, 785, 70-76. [CrossRef] [PubMed]

78. Selvaraj, J. Fatty Acids and Their Analogues as Anticancer Agents. Fatty Acids 2017, 21, 72-86. [CrossRef]

79. Chehade, L.A.; Angelini, L.G.; Tavarini, S. Genotype and Seasonal Variation Affect Yield and Oil Quality of Safflower (Carthamus tinctorius L.) under Mediterranean Conditions. Agronomy 2022, 12, 122. [CrossRef] 
80. Lamothe, L.M.; Lê, K.A.; Samra, R.A.; Roger, O.; Green, H.; Macé, K. The scientific basis for healthful carbohydrate profile. Crit. Rev. Food Sci. Nutr. 2017, 59, 1058-1070. [CrossRef] [PubMed]

81. Míguelez, J.d.1.M.; Bernárdez, M.M.; Queijeiro, J.M.G. Composition of varieties of chestnuts from Galicia (Spain). Food Chem. 2004, 84, 401-404. [CrossRef]

82. Borges, O.; Gonçalves, B.; de Carvalho, J.L.S.; Correia, P.; Silva, A.P. Nutritional quality of chestnut (Castanea sativa Mill.) cultivars from Portugal. Food Chem. 2008, 106, 976-984. [CrossRef]

83. Matraszek, R.; Hawrylak-Nowak, B.; Chwil, S.; Chwil, M. Macronutrient composition of nickel-treated wheat under different sulfur concentrations in the nutrient solution. Environ. Sci. Pollut. Res. 2016, 23, 5902-5914. [CrossRef]

84. Mensah, E.; Kyei-Baffour, N.; Ofori, E.; Obeng, G. Influence of Human Activities and Land Use on Heavy Metal Concentrations in Irrigated Vegetables in Ghana and Their Health Implications. In Appropriate Technologies for Environmental Protection in the Developing World; Sel. Pap. from ERTEP 2007; Springer: Dordrecht, The Netherlands, 2009; pp. 9-14. [CrossRef]

85. Udensi, U.K.; Tchounwou, P.B. Potassium Homeostasis, Oxidative Stress, and Human Disease. Int. J. Clin. Exp. Physiol. 2017, 4, 111. [CrossRef]

86. Sunyecz, J.A. The use of calcium and vitamin D in the management of osteoporosis. Ther. Clin. Risk Manag. 2008, 4, 827. [CrossRef]

87. Abbaspour, N.; Hurrell, R.; Kelishadi, R. Review on iron and its importance for human health. J. Res. Med. Sci. 2014, $19,164$.

88. Da Silva, E.C.; De Albuquerque, M.B.; Dias, A.; Neto, A.; Dias, C.; Junior, S. Drought and Its Consequences to Plants-From Individual to Ecosystem. In Responses of Organisms to Water Stress; IntechOpen: London, UK, 2013. [CrossRef]

89. Freitas, T.R.; Santos, J.A.; Silva, A.P.; Fraga, H. Influence of Climate Change on Chestnut Trees: A Review. Plants 2021, 10, 1463. [CrossRef] [PubMed]

90. De Vasconcelos, M.d.C.B.M.; Nunes, F.; Viguera, C.G.; Bennett, R.N.; Rosa, E.A.S.; Ferreira-Cardoso, J.V. Industrial processing effects on chestnut fruits (Castanea sativa Mill.) 3. Minerals, free sugars, carotenoids and antioxidant vitamins. Int. J. Food Sci. Technol. 2010, 45, 496-505. [CrossRef] 